\title{
FEASIBILITY ASSESSMENT OF BURNUP CREDIT IN THE CRITICALITY ANALYSIS OF SHIPPING CASKS WITH BOILING WATER REACTOR SPENT FUEL
}

\author{
B. L. Broadhead \\ Computing and Telecommunications Division \\ at Oak Ridge National Laboratory \\ P. O. Box 2008 \\ Oak Ridge, TN 37831-6370 \\ DATE PUBLISHED: August 1991
}

NOTICE: This document contains information of a preliminary nature. It is subject to revision or correction and therefore does not represent a final report.

\footnotetext{
Prepared under the direction of

Sandia National Laboratories

for the U.S. Department of Energy

Office of Civilian Radioactive Waste Management

Washington, DC 20585

MARTIN MARIETTA ENERGY SYSTEMS, INC.

managing the

Oak Ridge National Laboratory Oak Ridge Y-12 Plant

Oak Ridge Gaseous Diffusion Plant Paducah Gaseous Diffusion Plant for the

U.S. DEPARTMENT OF ENERGY

under contract DE-AC05-84OR21400
} 


\section{CONTENTS}

ACKNOWLEDGMENTS . . . . . . . . . . . . . . . ix ABSTRACT . . . . . . . . . . . . . . . . . . . $x i$

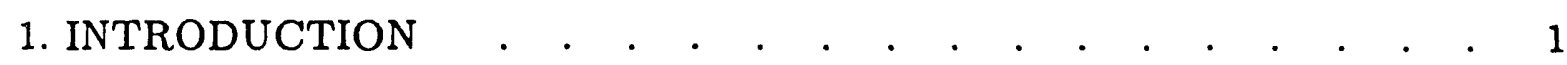

2. CALCULATIONAL TOOLS . . . . . . . . . . . . . . . . . 2

3. ONE-DIMENSIONAL MODEL DEVELOPMENT AND VERIFICATION 6

4. BURNUP PREDICTIONS . . . . . . . . . . . . . . . . . 11

4.1 SPECTRUM COMPARISONS . . . . . . . . . . . . . . . 11

4.2 AXIAL POWER DISTRIBUTION ASSUMPTIONS . . . . . 17

4.3 AXIAL ISOTOPIC VARIATIONS . . . . . . . . . . . . . 24

5. REACTIVITY PREDICTIONS . . . . . . . . . . . . . 26

5.1 REACTIVITY TREND CURVES . . . . . . . . . . . 26

5.2 CONTROL REQUIREMENTS . . . . . . . . . . . . . . . 32

5.3 BASKET WORTHS . . . . . . . . . . . . . . . . . . . 32

6. SUMMARY . . . . . . . . . . . . . . . . . . 35

7. REFERENCES . . . . . . . . . . . . . . . . . . . 37 


\section{LIST OF FIGURES}

Fig.

Page

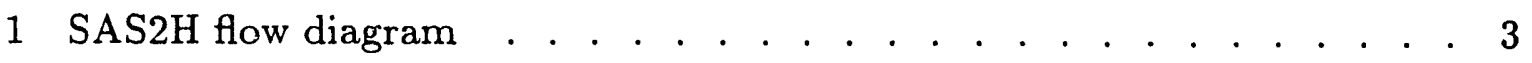

2 CSAS4 flow diagram . . . . . . . . . . . . . . . . . . . 4

3 BWR assembly schematic, 40-GWd/MTU case . . . . . . . . . . . . 7

4 SAS2H treatment of $\mathrm{Gd}$ rods and water channel effects . . . . . . . . 9

5 Assumed axial power distributions . . . . . . . . . . . . . . . . . 20

$6 \mathrm{k}_{\infty}$ versus burnup for tailored axial power assumptions . . . . . . . . 21

$7 \mathrm{k}_{\infty}$ versus burnup for flat axial power assumptions . . . . . . . . . . 22

$8 k_{\infty}$ versus burnup for constant axial power assumption and one-axial-node case (denoted by $\mathrm{x}$ ) . . . . . . . . . . . . . . . 23

$9 \quad k_{\infty}$ as a function of burnup and cooling time for $2.5 \mathrm{wt} \%$ initial enrichment fuel . . . . . . . . . . . . . . . . . . . . . . . 27

$10 \mathrm{k}_{\infty}$ as a function of burnup and cooling time for $2.9 \mathrm{wt} \%$ initial enrichment fuel . . . . . . . . . . . . . . . . . . . . . . . 28

$11 \mathrm{k}_{\infty}$ as a function of burnup and cooling time for $3.4 \mathrm{wt} \%$ initial enrichment fuel . . . . . . . . . . . . . . . . . . . . . . . 29

$12 \mathrm{k}_{\infty}$ as a function of burnup and cooling time for $3.8 \mathrm{wt} \%$ initial enrichment fuel . . . . . . . . . . . . . . . . . . . . . . . 30

$13 \mathrm{k}_{\infty}$ values for various axial power assumptions for $3.4 \%$ initial enrichment at the end of 40-GWd/MTU burnup . . . . . . . . 31

14 Composite steel-boral basket model . . . . . . . . . . . . . . . . . 33 


\section{LIST OF TABLES}

Table

Page

1 Neutron group structure for SCALE 27-group library . . . . . . . . . 5

2 Fuel enrichments of typical BWR assembly for 40-GWd/MTU case . . . 8

3 Axial water censities of typical BWR . . . . . . . . . . . . . . . . 8

4 Comparison of various approximations for BWR fuel modeling . . . . . 10

5 Comparison of fissions and absorptions of split enrichment vs average enrichment fuel elements for bottom node (3.4\% initial enrichment) . . . 12

6 Comparison of spectra of split enrichment vs average enrichment fuel elements for bottom node (3.4\% initial enrichment) . . . . . . . . . . 13

7 Comparison of 1-D vs 2-D spectra for bottom node, Gd assemblies (3.4\% initial enrichments) . . . . . . . . . . . . . . . . . . . . 14

8 Comparison of 1-D vs 2-D spectra for top node, $\mathrm{Gd}$ assemblies (3.4\% initial enrichment) . . . . . . . . . . . . . . . . . . . . . . 15

9 Comparison of $1-D$ vs $2-D$ spectra for top node, non-Gd assembly (3.4\% initial enrichment) . . . . . . . . . . . . . . . . . . . . . 16

10 Comparison of spectral differences (fission fraction by group) in top, middle, and bottom nodes in BWR fuel assembly . . . . . . . . . . . 18

11 Comparison of spectral differences (absorption fraction by group) in top, middle, and bottom nodes in BWR fuel assembly . . . . . . . . . 19

12 One-node vs three-node isotopic comparison (atoms/b-cm) at end of $40 \mathrm{GWd} / \mathrm{MTU}$ for $3.4 \%$ initially enriched BWR fuel . . . . . . . . . . 25

13 Effect of flat vs tailored specific power burnup assumption on isotopic compositions (atoms/b-cm) at end of $40 \mathrm{GWd} / \mathrm{MTU}$ for $3.4 \%$ initial enrichment BWR fuel . . . . . . . . . . . . . . . . . . . . 25

14 Control requirements afier two-year cooling times . . . . . . . . . . . 33

15 Basket worths for borated and non-borated webs . . . . . . . . . . . 34 


\section{INTRODUCTION}

Considerable interest in the allowance of reactivity credit for the exposure history of power reactor fuel currently exists. This "burnup credit" issue has the potential to greatly reduce risk and cost when applied to the design and certification of spent fuel casks used for transportation and storage. Recently, analyses ${ }^{1}$ have demonstrated the technical feasibility and estimated the risk and economic incentives for allowing burnup credit in pressurized water reactor (PWR) spent fuel shipping cask applications. This report summarizes the extension of the previous PWR technical feasibility assessment to boiling water reactor (BWR) fuel. As with the PWR analysis, the purpose was not verification of burnup credit (see ref. 2 for ongoing work in this area) but a reasonable assessment of the feasibility and potential gains from its use in BWR applications.

This feasibility analysis aims to apply simple methods that adequately characterize the time-dependent isotopic compositions of typical BWR fuel. An initial analysis objective was to identify a simple and reliable method for characterizing BWR spent fuel. Two different aspects of fuel characterization were considered: first, the generation of burnup-dependent material interaction probabilities; second, the prediction of material inventories over time (depletion). The generation of burnup-dependent libraries is generally accomplished via a simple characterization of a typical pin-cell spectrum, which in turn allows for few-group material constants to be generated. These spectrum calculations generally involve one-dimensional (1D) transport analyses; therefore, the first phase of the analysis attempted to obtain a reliable procedure using one-dimensional (1-D) capabilities. Point depletion methods were then used to obtain the time-varying characteristics of the fuel. These simple methods were validated, where practical, with multidimensional methods.

After characterizing the spent fuel at various stages of exposure and decay, three-dimensional (3-D) models for an infinite array of assemblies and, in several cases, infinite arrays of assemblies in a typical shipping cask basket were analyzed. Results for assemblies without a basket provide reactivity control requirements as a function of burnup and decay, while results including the basket allow assessment of typical basket configurations to provide sufficient reactivity control for spent BWR fuel. Resulting basket worths and reactivity trends over time are then evaluated to determine whether burnup credit is needed and feasible in BWR applications. 


\section{CALCULATIONAL TOOLS}

The primary computational tools used in this analysis were the SAS2H, CSAS25, and CSASIX sequences from Version 4 of the SCALE system. ${ }^{3,4}$ Figures 1 and 2 show these sequences schematically.

The SAS2H sequence comprises the repetitive application of the BONAMI (cross-section processing), NITAWL (resonance processing), XSDRNPM (1-D transport spectrum calculation), COUPLE (ORIGEN-S library generation), and ORIGEN-S (point depletion isotopics) to yicld detailed isotopics at specified time points throughout the operating cycle of the fuel. The SAS2H sequence also allows the addition of a second spectrum calculation at each time point. This gives added flexibility, as the first spectrum calcuiation is generally for an infinite array of pins (pin-cell calculation), while the second step can then model a water hole (PWR) or gadolinium rod (BWR) surrounded by the pin-cell material from the first step. The SAS2H spectrum calculations also yield a trace of the $k_{\infty}$ values at specified times during the reactor operating cycle for the 1-D models. The isotopic information generated by the point depletion computations can then be input to multidimensional codes for criticality analysis in a shipping cask environment.

The multidimensional calculations of an infinite array of BWR assemblies with and without intervening basket materials were performed with the CSAS25 sequence. These calculations were performed for typical shipping cask conditions, although the cask body itself was not modeled. The models consisted of an infinite array of assemblies separated by either water or a steel/boral basket material. The CSAS25 sequence performs the same cross-section operations as SAS2H (i.e., BONAMI and NITAWL codes), then calls and executes KENO V.a, a multidimensional Monte Carlo criticality code. These calculations allow $\mathrm{k}_{\infty}$ (or $\mathrm{k}_{e f f}$ for a finite array of assemblies) to be determined in a hypothetical shipping cask array as a function of burnup and cooling.

The final SCALE module used in this study was CSASIX. Figure 2 also shows the flow diagram for CSASIX; BONAMI and NITAWL again provide cross-section processing services, followed by a spectrum calculation in XSDRNPM. The resultant cell-weighted cross-section library (from XSDRNPM) is then passed to the ICE code, which produces a mixed (macroscopic) cross-section library. After some additional format conversion (AMPX to ANISN libraries), these libraries are used in the DORT code. ${ }^{5}$ The DORT code is an updated version of the widely available DOT two-dimensional (2-D) discrete ordinates transport code. The 2-D transport analyses provided confirmatory calculations for the 1-D SAS2H results.

The base cross-section library used in this study was the SCALE 27-neutrongroup ENDF/B-IV library (see Table 1), which was enhanced with additional fission product nuclides appropriate for spent fuel applications. The base library has been extensively tested and validated ${ }^{6}$ for fresh fuel applications. This library contains 13 thermal groups with upscatter up to $3 \mathrm{eV}$. The library also contains resonance information for the NITAWL module, which applies the Nordheim integral treatment to account for problem-dependent resonance self-shielding effects. 

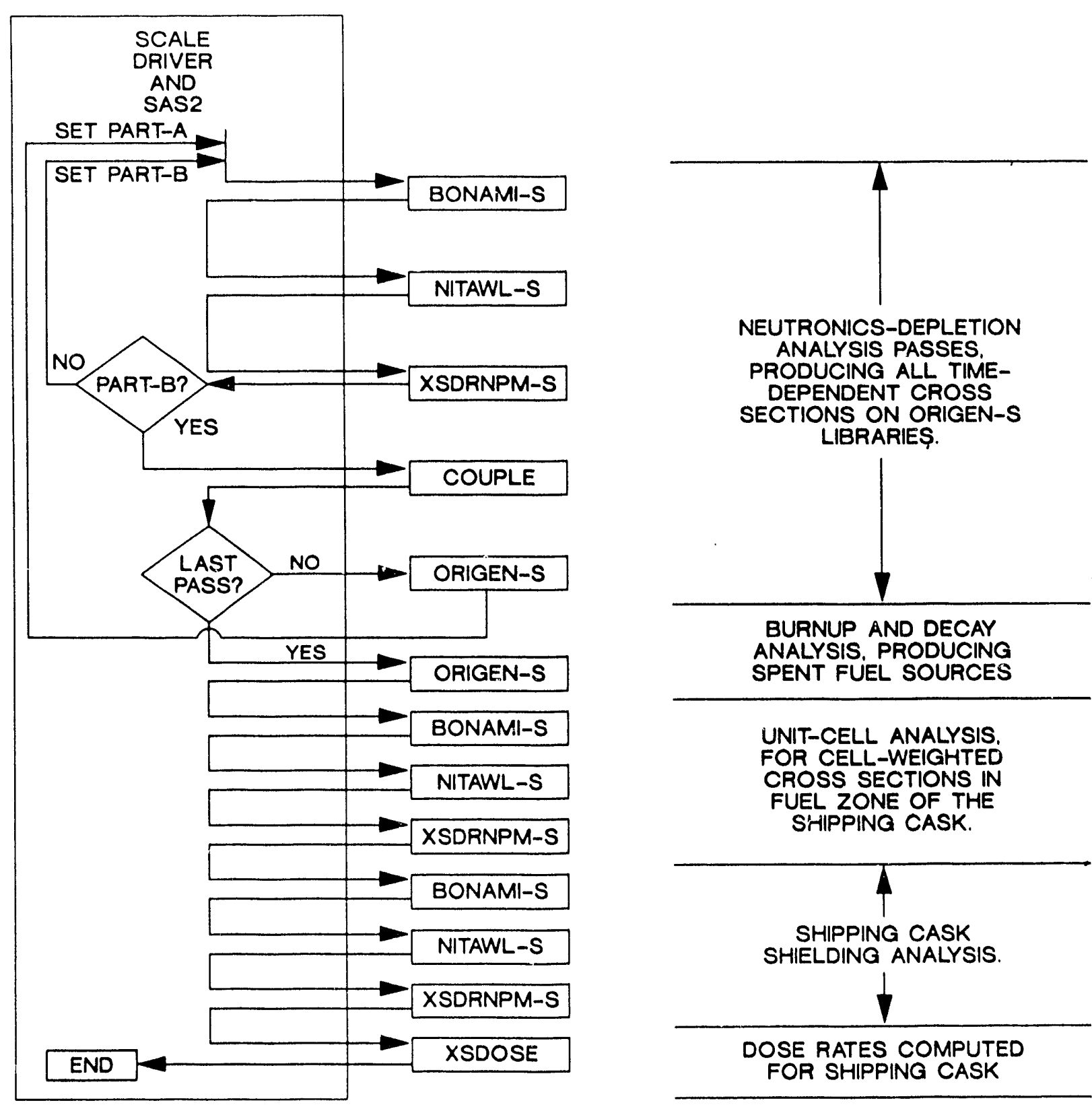

NEUTRONICS-DEPLETION ANALYSIS PASSES. PRODUCING ALL TIMEDEPENDENT CROSS SECTIONS ON ORIGEN-S LIBRARIES.

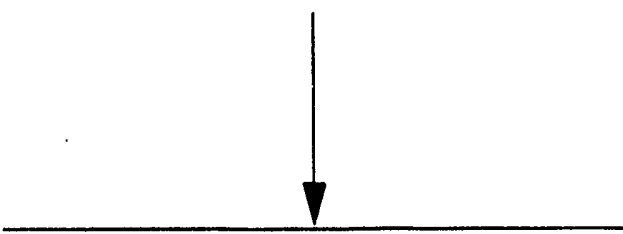

BURNUP AND DECAY ANALYSIS, PRODUCING SPENT FUEL SOURCES

UNIT-CELL ANALYSIS

FOR CELL-WEIGHTED

CROSS SECTIONS IN

FUEL ZONE OF THE SHIPPING CASK.

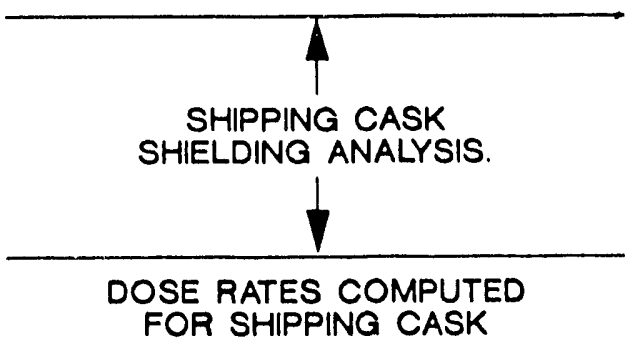

Fig. 1. SAS2H flow diagram. 


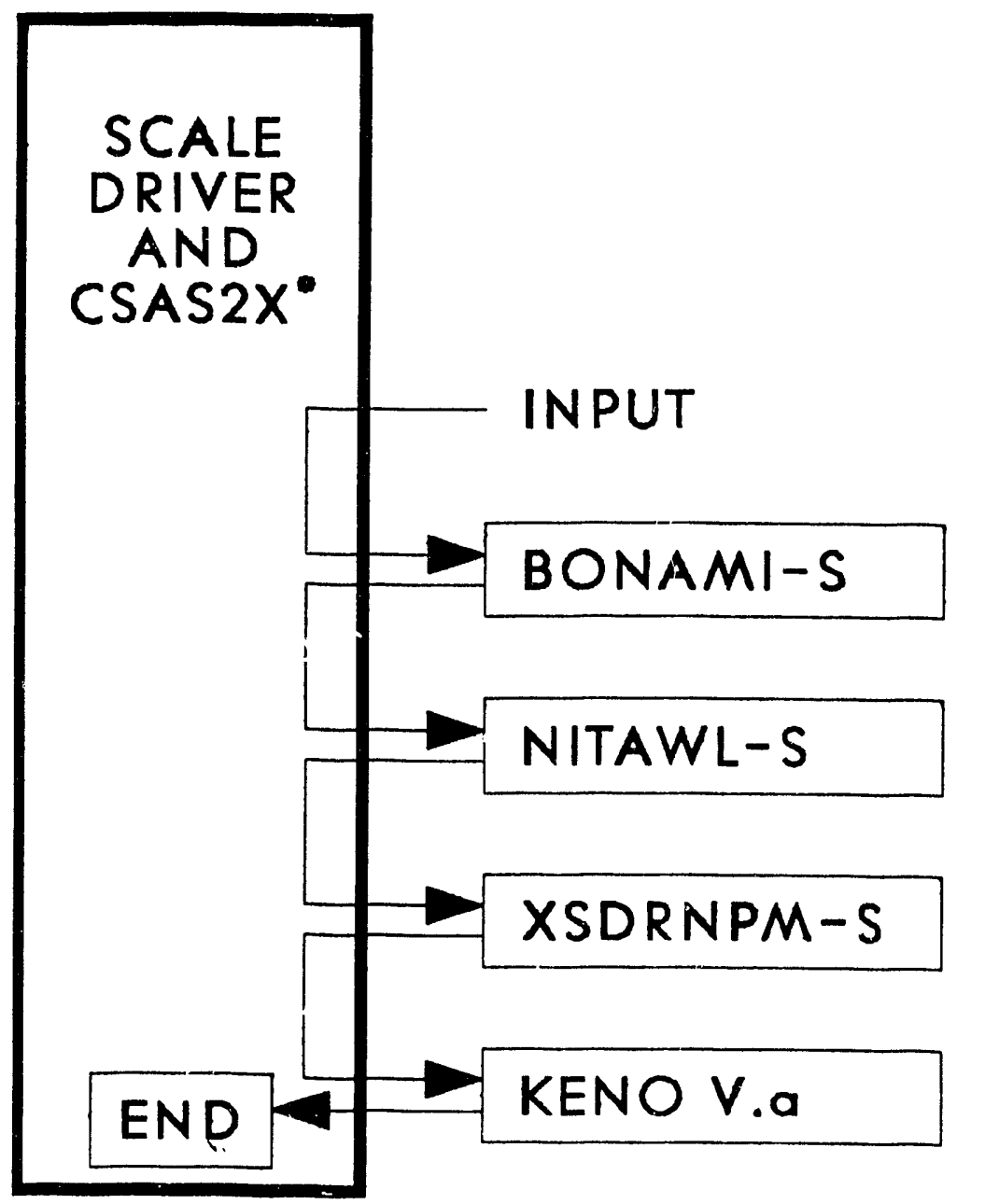

Resonance
self-shielding

Cell-weighting of cross section Monte Carlo k eff calculation

- CSASIX terminates after the call to XSDRNPM-S

CSAS 25 omits XSDRNPM-S call

CSAS I umits the calls to XSDRNPM-S and KENO V.a and calls ICE-S instead

CSASIX omits the call to KENO V.a and calls ICE-S instead CSASN terminates after the call to NITAWL

Fig. 2. CSAS4 flow diagram. 
Table 1. Neutron group structure for SCALE 27-group library

\begin{tabular}{cc}
\hline $\begin{array}{c}\text { Group } \\
\text { number }\end{array}$ & $\begin{array}{c}\text { Upper energy } \\
\text { limit }(\mathrm{eV})\end{array}$ \\
\hline 1 & $2.00+7^{\circ}$ \\
2 & $6.43+6$ \\
3 & $3.00+6$ \\
4 & $1.85+6$ \\
5 & $1.40+6$ \\
6 & $9.00+5$ \\
7 & $4.00+5$ \\
8 & $1.00+5$ \\
9 & $1.70+4$ \\
10 & $3.00+3$ \\
11 & $5.50+2$ \\
12 & $1.00+2$ \\
13 & $3.00+1$ \\
14 & $1.00+1$ \\
15 & 3.05 \\
16 & 1.77 \\
17 & 1.30 \\
18 & 1.13 \\
19 & 1.00 \\
20 & $8.00-1$ \\
21 & $4.00-1$ \\
22 & $3.25-1$ \\
23 & $2.25-1$ \\
24 & $1.00-1$ \\
25 & $5.00-2$ \\
26 & $3.00-2$ \\
\hline $1.00-2$ \\
\hline
\end{tabular}

a Read as $2 \times 10^{7}$. 


\section{ONE-DIMENSIONAL MODEL DEVELOPMENT AND VERIFICATION}

Accurate prediction of spent fuel isotopics in a BWR fuel assembly requires a 3-D time-dependent approach. In this effort, a series of well-known 1-D methods approximated the complex physical situation. Specifically, a three-step procedure (SAS2H code) produces time-dependent isotopic distributions. First, a pin-cell calculation produces cell-weighted cross sections that are passed to an assembly calculation. The assembly calculation produces zone-dependent spectra used to collapse the groupwise cross sections into a single group. These one-group cross sections are then used in a point-depletion code to obtain the time-dependent isotopic information. These one-group cross sections and the isotopics are values averaged across the entire assembly (in essence, the material densities are constant over the entire assembly). With substantial axial variations in either the fuel or moderator materials, special care must be taken to accurately model the fuel burnup with point-depletion methods. In particular, BWRs contain substantial axial variations in moderator density. Standard means of representing this variation use multiple axial nodes; in each node, the material densities (boih fresh and burned) are constant across the node. A number of approximations exist in such an approach; however, where possible, verification should allow for more confidence to be placed in the procedures.

The BWR assembly model used in this analysis corresponds to a typical BWR assembly description (see Fig. 3). The model and corresponding data (Tables 2 and 3 ) are taken from ref. 7 . Initial efforts involved an investigation of the accuracy of the 1-D criticality predictions for the BWR fuel element model shown in Fig. 3. Five effects were investigated: (1) water channel reactivity effects, (2) the appropriate assembly model with and without gadolinium (Gd) rods, (3) the Gd rod reactivity effects, (4) three-axial-node versus one-axial-node reactivities, and (5) use of average pin enrichments $(3.4 \%$ ) versus split pin enrichments (shown in Table 2). The specific mod sls used in the SAS2H procedure varied depending on the inclusion or exclusion of the Gd rods. Figure 4 shows the 1-D assembly representation for both cases. The initial pin-cell calculation was identical for both cases. For the second-step calculation of the assembly without Gd rods, the full assembly was converted to an equivalent volume cylinder (Fig. 4a). The inclusion of the Gd rods presented modeling difficulties because of their irregular distribution within the assembly. Three different methods of treating these Gd rod effects were attempted. The first involved modeling the entire assembly with all six Gd rods placed in the center of the assembly (see Fig. 3). The reactivity for this case was nearly the same as the assembly without Gd rods. The second scenario was to smear the Gd rods uniformly over the entire assembly; this greatly enhanced the Gd effectiveness and resulted in a halving of the $\mathrm{k}_{\infty}$ value. The third method consisted of a 1,6 assembly model (shown in Fig. 4b and discussed in the next section) and produced more consistent results.

Table 4 gives the results of this initial model development and verification effort. These results are presented for three equally spaced axial nodes. Both the 1- and $2-\mathrm{D}$ results treat each axial noade as an independent calculation, while the 3-D KENO V.a calculation treats all nodes simultaneously. For the non-Gd assembly cases, the water channel effects are seen to be significant in the top axial node, with the $\mathrm{k}_{\infty}$ value increasing from 1.05 (a pin-cell calculation as in Fig. 4, in which only 


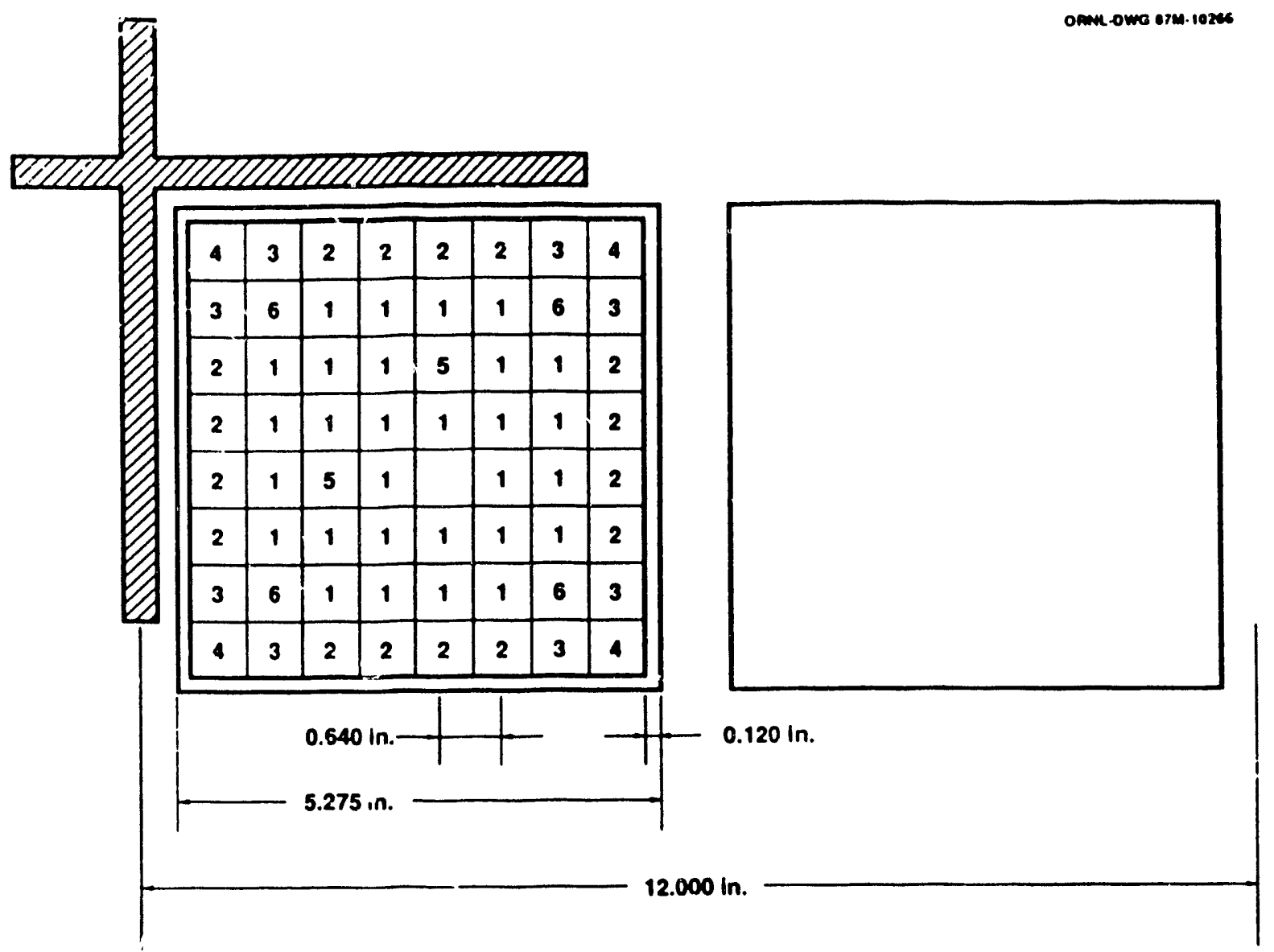

Fig. 3. BWR assembly schematic, 40-GWd/MTU case. 
Table 2. Fuel enrichments of typical BWR assembly for 40-GWd/MTU case

\begin{tabular}{ll}
\hline Type and number & Wt $\%{ }^{235} \mathrm{U}$ enrichment \\
\hline Type 1: 29 rods & 4.15 \\
Type 2: 16 rods & 2.90 \\
Type 3: 8 rods & 2.65 \\
Type 4: 4 rods & 2.00 \\
Type 5: 2 rods & $4.15,2$ wt $\% \mathrm{Gd}_{2} \mathrm{O}_{3}$ \\
Type 6: 4 rods & $2.90,3$ wt $\% \mathrm{Gd}_{2} \mathrm{O}_{3}$ \\
\hline
\end{tabular}

Table 3. Axial water densities of typical BWR

\begin{tabular}{|c|c|c|c|}
\hline $\begin{array}{c}\text { Top of node, } \\
\text { Z, in. }\end{array}$ & $\begin{array}{c}\text { Density at Z, } \\
\text { g- } \mathrm{cm}^{-3}\end{array}$ & $\begin{array}{l}\text { A verage density } \\
\text { in node, } \mathrm{g}-\mathrm{cm}^{-3}\end{array}$ & $\begin{array}{c}\text { Average water } \\
\text { temperature, }{ }^{\circ} \mathrm{K}\end{array}$ \\
\hline 30.83 & 0.692 & 0.743 & 552 \\
\hline 43.17 & 0.569 & 0.600 & 558 \\
\hline 55.50 & 0.472 & 0.494 & 558 \\
\hline 67.83 & 0.400 & 0.417 & 558 \\
\hline 80.17 & 0.347 & 0.360 & 558 \\
\hline 98.67 & 0.293 & 0.309 & 558 \\
\hline 123.33 & 0.250 & 0.264 & 558 \\
\hline 148.00 & 0.228 & 0.234 & 558 \\
\hline
\end{tabular}




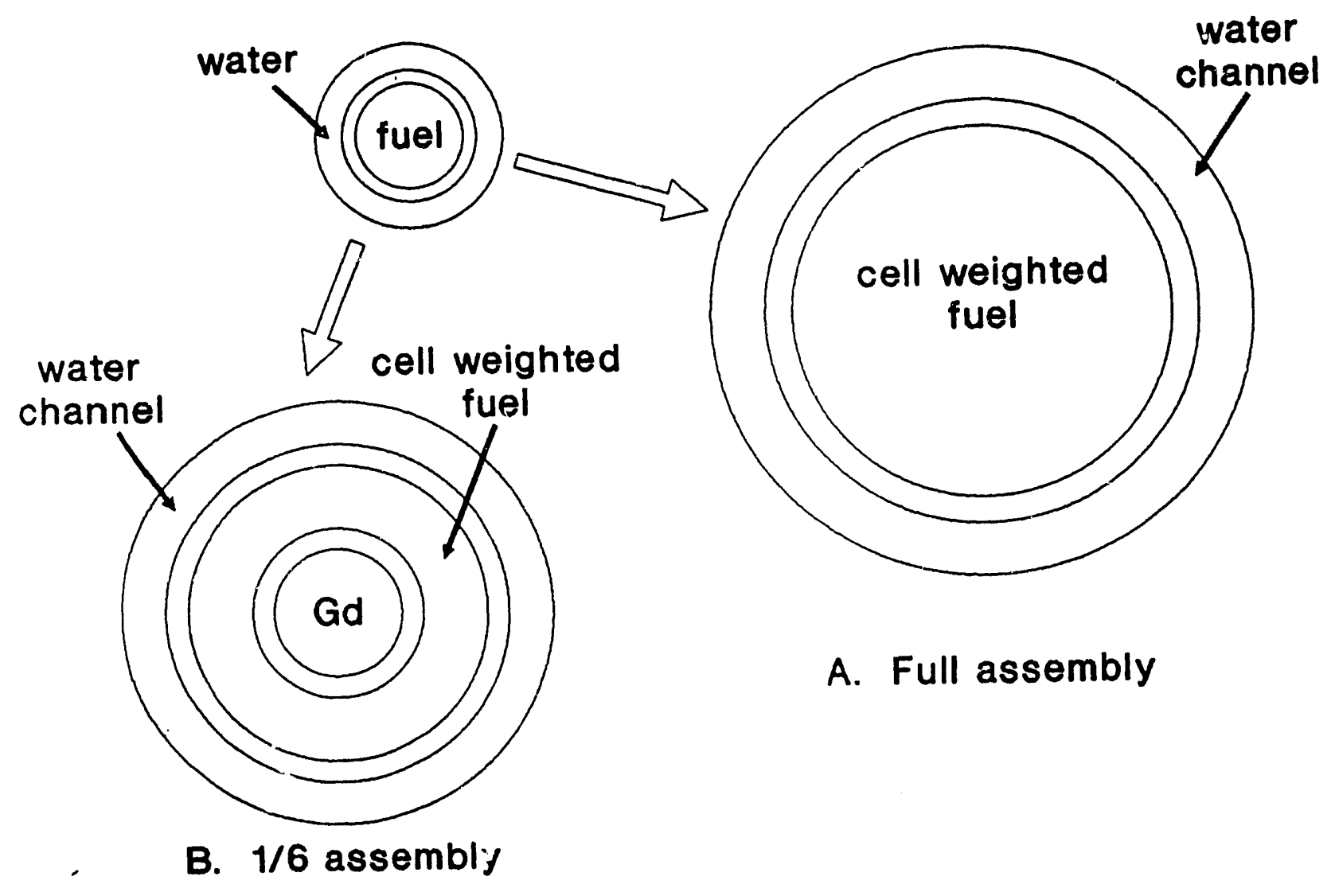

Fig. 4. SAS2H trsatment of Gd rods and water channel effects. 
the pin and surrounding low-density moderator are treated) to 1.33 , with the inclusion of the high-density water channel (treated by the SAS2H full assembly model as in Fig. 4a). The effects are less striking for the bottom node, which contains very nearly the same water densities inside and outside of the fuel channel. The agreement between the 1-D SAS2H and the 2-D DORT (modeled in $x-y$ geometry with cell-weighted fuel cross sections) results using a 3.4\% average enrichment is very good. Similarly, the KENO V.a result compares well with the thiee-node values.

The 1-D model used to spproximate the assembly containing Gd rods (see Fig. 4b) represented a single Gd rod, surrounded by one-sixth of the assembly fuel, clad, and channel water (the assembly contains a total of six Gd rods). The 2-D DORT model for an assembly with Gd rods again uses $x-y$ geometry but utilizes separate cell-weighted cross-section sets for standard fuel pins and Gd fuel pins. Based on the results in Table 4, the 1-D representation of a Gd assembl:" is not as accurate as that for the assembly without Gd rods. The 1-D results for the Gd assembly are higher by $4-5 \% \Delta \mathrm{k}$ than the corresponding 2-D resuits. Apparently, this overprediction primorily stems from the inaccurate rep-esentation of the Gd rod position in the assembly. A separate calculation was performed with the one-sixth model for the non-Gd assembly, producing a $1 \% \Delta \mathrm{k}$ difference with the multidimensional results. Thus, the remaining discrepancy should be due to the approximate representation of the Gd rod locations. Again, the KENO V.a value agrees with the three-node $2-D$ values.

All cases thus far have assumed an average enrichment across the assembly. The final two results shown in Table 4 give $k_{\infty}$ values: first for the pin-split enrichments of Table 2, then assuming all pins contain the peak enrichisent (4.15 wt \%). The 2-D actual pin split enrichment reactivity is only $2 \% \Delta \mathrm{k}$ lower than the 2-D average enrichment case. Thus, the average enrichment assumption appears to be sufficiently accurate for this series of scoping calculations. The peak enrichment case produces a $\mathrm{k}_{\infty}$ value of 1.20 for the bottom node case, which is substantially higher than either the pin-split or average enrichment DORT results.

The 1-D model chosen for the remaining analyses consists of an average enriched, one-sixth assembly, Gd-rod model which accounts for the water channel and Gd rod effects. The material density axial variations are accounted for by the use of threeaxial-nodes.

Table 4. Comparison of various approximations for BWR fuel modeling

\begin{tabular}{lccc}
\hline & \multicolumn{3}{c}{$\mathrm{k}_{\infty}$ Values $^{a}$} \\
\cline { 3 - 4 } & Top node & Middle node & Bottom node \\
\hline Without Gd rods & & & \\
DORT (2-D) & 1.33 & 1.34 & 1.37 \\
SAS2H (full assembly) & 1.33 & 1.34 & 1.37 \\
Pin cell & 1.05 & 1.17 & 1.32 \\
With Gd rods & & & \\
D'JKT (2-D) & 1.08 & 1.10 & 1.12 \\
SAS2H (1/6 assembly) & 1.12 & 1.14 & 1.17 \\
DORT (actual pin-split & - & - & 1.10 \\
enrichments of Table 2) & - & - & 1.20 \\
DORT (rnaximum enrichments 4.15\%) & - & - & \\
\hline
\end{tabular}

$3.4 \%$ initial average enrichment unless otherwise noted.

${ }^{6} \mathrm{KENO}$ V.a (3-D) value is 1.35

${ }^{c}$ KENO V.a (3-D) value is 1.12 


\section{BURNUP PREDICTIONS}

All cases analyzed thus far have been for fresh fuel to establish a valid 1-D model for the remaining analysis. In the case of the reactivity comparisons, it was possible to compare $1-D$ versus $2-$ and $3-D$ results to estimate the validity of the calculations. For the case of burned fuel, this direct comparison was not attempted. However, a comparison of the spectra and, in some cases, the fission fraction by neutron group (fission fractions) and the absorption fraction by neutron group (absorption fractions) was performed. The fission and absorption rates are directly the loss and/or generation rates for actinide materials; thus, the fraction by group of these quantities constitutes an importance measure for actinide production and loss. However, the 1-D and 2-D code outputs present absorptions and fissions in different manners; thus, direct comparisons are presented only for the 2-D split enrichment to $2-D$ average enr.chment case. The following section compares the spectra from several of the cases shown in Sect. 3 .

\subsection{SPECTRUM COMPARISONS}

Neutron spectrum differences give rise to isotopic differences during depletion. A comparison of fresh fuel spectra for the various model approximations shown in Sect. 3 were performed to estimate the potential impact on the depleted isotopics. Table 5 gives the comparison for two different DORT 2-D Gd assembly calculations based on explicit pin-split enrichments and the average pin enrichment. Both fission fractions and absorption fractions are giver, with good agreement seen in both cases (generally less than $1 \%$ difference for fissions and $2 \%$ for absorptions). This comparison is for the bottom node; however, the middle and top node results should be quite similar because both are results of 2-D calculations. Table 6 presents the direct flux spectrum comparison for the same 2-D cases. For all groups above $0.3 \mathrm{eV}$ (group 22), the agreement is very good (generally $1 \%$ differences or less). For energies below $0.3 \mathrm{eV}$, the Gd-155 and Gd-157 cross sections rise rapidly, and the use of average enrichments in the Gd rods appears to cause the $6 \%$ underprediction of the flux.

The results for a similar comparison of the same 2-D bottom node average enrichment case to a 1-D average enrichment case are given in Table 7. Because of analysis difficulties for 1-D to 2-D comparisons, these comparison results are for the flux spectra only. As can be seen in Tables 5 and 6 , the fission and absorption fractions generally agree better than the flux spectrum because of cancellation effects. The flux spectra generally agree to within $3 \%$ for energies greater than $0.3 \mathrm{eV}$, with differences of nearly $20 \%$ seen for lower energies. As stated earlier, the fission and absorption rates are expected to agree more than the flux spectra. These differences result from the geometric approximations necessary to model the Gd-pin assembly in 1-D. The same comparisons are given in Table 8 for the top node. As expected, there is less agreement here between 1-D and 2-D spectra. The lower density/high density moderation changes across an assembly are more difficult to represent in 1-D than in 2-D.

The flux spectrum differences and hence the fission and absorption rate differences seen in Tables 5-8 are not a major cause for concern in the prediction of burnup and production results because the representation of the Gd appears to be the major cause of these differences. The Gd typically disappears very rapidly during reactor operation. Table 9 shows the corresponding 1-D to 2-D flux spectrum 
Table 5. Comparison of fissions and absorptions of split enrichment vs average enrichment fuel elements for bottom node ( $3.4 \%$ initial enrichment)

\begin{tabular}{|c|c|c|c|c|c|c|}
\hline $\begin{array}{c}\text { Group } \\
\text { no. }\end{array}$ & $\begin{array}{l}\text { Fractional } \\
\text { fissions } \\
\text { (split) }\end{array}$ & $\begin{array}{l}\text { Fractional } \\
\text { fissions } \\
\text { (average) }\end{array}$ & $\begin{array}{c}\text { Split/ } \\
\text { average }\end{array}$ & $\begin{array}{l}\text { Fractional } \\
\text { absorption } \\
\text { (split) }\end{array}$ & $\begin{array}{c}\text { Fractional } \\
\text { absorption } \\
\text { (average) }\end{array}$ & $\begin{array}{c}\text { Split/ } \\
\text { average }\end{array}$ \\
\hline 1 & $6.48-3$ & $6.41-3$ & 1.011 & $3.04-3$ & $3.05-3$ & 0.997 \\
\hline 2 & $2.30-2$ & $2.27-2$ & 1.013 & $1.12-2$ & $1.12-2$ & 1.000 \\
\hline 3 & $2.48-2$ & $2.45-2$ & 1.012 & $1.11-2$ & $1.12-2$ & 0.991 \\
\hline 4 & $1.03-2$ & $1.02-2$ & 1.010 & $5.32-3$ & $5.36-3$ & 0.993 \\
\hline 5 & $3.13-3$ & $3.09-3$ & 1.013 & $3.34-3$ & $3.36-3$ & 0.994 \\
\hline 6 & $2.82-\tilde{3}$ & $2.77-3$ & 1.018 & $5.07-3$ & $5.14-3$ & 0.986 \\
\hline 7 & $2.82-3$ & $2.78-3$ & 1.014 & $5.41-3$ & $5.49-3$ & 0.985 \\
\hline 8 & $2.90-3$ & $2.87-3$ & 1.010 & $9.11-3$ & $9.28-3$ & 0.982 \\
\hline 9 & $3.99-3$ & $3.96-3$ & 1.008 & $1.56-2$ & $1.59-2$ & 0.981 \\
\hline 10 & $8.48-3$ & $8.43-3$ & 1.006 & $2.38-2$ & $2.43-2$ & 0.979 \\
\hline 11 & $1.76-2$ & $1.75-2$ & 1.006 & $3.91-2$ & $3.99-2$ & 0.980 \\
\hline 12 & $2.24-2$ & $2.25-2$ & 0.996 & $4.17-2$ & $4.25-2$ & 0.981 \\
\hline 13 & $2.09-2$ & $2.10-2$ & 0.995 & $3.88-2$ & $3.96-2$ & 0.980 \\
\hline 14 & $1.60-2$ & $1.61-2$ & 0.994 & $5.19-2$ & $5.28-2$ & 0.983 \\
\hline 15 & $4.11-3$ & $4.11-3$ & 1.000 & $8.35-3$ & $8.46-3$ & 0.987 \\
\hline 16 & $2.78-3$ & $2.77-3$ & 1.004 & $3.45-3$ & $3.49-3$ & 0.989 \\
\hline 17 & $4.21-3$ & $4.22-3$ & 0.998 & $3.43-3$ & $3.48-3$ & 0.986 \\
\hline 18 & $5.61-3$ & $5.62-3$ & 0.998 & $3.85-3$ & $3.91-3$ & 0.985 \\
\hline 19 & $6.83-3$ & $6.83-3$ & 1.000 & $5.03-3$ & $5.10-3$ & 0.986 \\
\hline 20 & $2.94-2$ & $2.94-2$ & 1.000 & $2.28-2$ & $2.31-2$ & 0.987 \\
\hline 21 & $1.77-2$ & $1.77-2$ & 1.000 & $1.38-2$ & $1.40-2$ & 0.986 \\
\hline 22 & $5.19-2$ & $5.20-2$ & 0.998 & $4.32-2$ & $4.35-2$ & 0.993 \\
\hline 23 & $1.93-1$ & $1.93-1$ & 1.000 & $1.89-1$ & $1.87-1$ & 1.011 \\
\hline 24 & $2.29-1$ & $2.29-1$ & 1.000 & $2.05-1$ & $2.03-1$ & 1.010 \\
\hline 25 & $1.34-1$ & $1.35-1$ & 0.993 & $1.13-1$ & $1.12-1$ & 1.009 \\
\hline 26 & $1.23-1$ & $1.23-1$ & 1.000 & $9.92-2$ & $9.81-2$ & 1.011 \\
\hline 27 & $3.30-2$ & $3.27-2$ & 1.009 & $2.65-2$ & $2.59-2$ & 1.023 \\
\hline
\end{tabular}


Table 6. Comparison of spectra of split enrichment vs average enrichment fuel elements for bottom node ( $3.4 \%$ initial enrichment)

\begin{tabular}{|c|c|c|c|}
\hline $\begin{array}{c}\text { Group } \\
\text { no. }\end{array}$ & $\begin{array}{c}\text { Flux } \\
\text { spectrum } \\
\text { (split) }\end{array}$ & $\begin{array}{c}\text { Flux } \\
\text { spectrum } \\
\text { (average) }\end{array}$ & $\begin{array}{l}\text { Split/ } \\
\text { average }\end{array}$ \\
\hline 1 & $7.62-3$ & $7.56-3$ & 0.995 \\
\hline 2 & $5.19-2$ & $5.23-2$ & 0.992 \\
\hline 3 & $6.34-2$ & $6.40-2$ & 0.991 \\
\hline 4 & $3.90-2$ & $3.94-2$ & 0.990 \\
\hline 5 & $5.77-2$ & $5.83-2$ & 0.990 \\
\hline 6 & $1.03-1$ & $1.04-1$ & 0.990 \\
\hline 7 & $9.91-2$ & $1.01-1$ & 0.981 \\
\hline 8 & $7.24-2$ & $7.35-2$ & 0.985 \\
\hline 9 & $5.66-2$ & $5.74-2$ & 0.986 \\
\hline 10 & $5.21-2$ & $5.29-2$ & 0.985 \\
\hline 11 & $4.91-2$ & $4.98-2$ & 0.986 \\
\hline 12 & $3.20-2$ & $3.24-2$ & 0.988 \\
\hline 13 & $2.80-?$ & $2.82-2$ & 0.993 \\
\hline 14 & $2.74-2$ & $2.76-2$ & 0.993 \\
\hline 15 & $1.56-2$ & $1.58-2$ & 0.987 \\
\hline 16 & $8.82-3$ & $8.90--3$ & 0.991 \\
\hline 17 & $3.94-3$ & $3.97-3$ & 0.992 \\
\hline 18 & $3.39-3$ & $3.41-3$ & 0.994 \\
\hline 19 & $6.29-3$ & $6.34-3$ & 0.992 \\
\hline 20 & $2.11-2$ & $2.12-2$ & 0.995 \\
\hline 21 & $7.38-3$ & $7.34-3$ & 1.005 \\
\hline 22 & $1.80-2$ & $1.76-2$ & 1.023 \\
\hline 23 & $6.93-2$ & $6.62--2$ & 1.047 \\
\hline 24 & $5.91-2$ & $5.58-2$ & 1.059 \\
\hline 25 & $2.65-2$ & $2.50-2$ & 1.060 \\
\hline 26 & $1.83-2$ & $1.72-2$ & 1.064 \\
\hline 27 & $3.24-3$ & $3.03-3$ & 1.069 \\
\hline
\end{tabular}


Table 7. Comparison of 1-D vs 2-D spectra for bottom node, Gd assemblies (3.4\% initial enrichment)

\begin{tabular}{|c|c|c|c|}
\hline $\begin{array}{c}\text { Group } \\
\text { no. }\end{array}$ & $\begin{array}{c}\text { Flux } \\
\text { spectrum } \\
(1-D \text { avg) }\end{array}$ & $\begin{array}{c}\text { Flux } \\
\text { spectrum } \\
(2-D \text { avg })\end{array}$ & $\begin{array}{l}1-D \text { avg/ } \\
2-D \text { avg }\end{array}$ \\
\hline 1 & $7.24-3$ & $7.66-3$ & 0.945 \\
\hline 2 & $5.30-2$ & $5.23-2$ & 1.013 \\
\hline 3 & $6.60-2$ & $6.40-2$ & 1.031 \\
\hline 4 & $4.07-2$ & $3.94--2$ & 1.033 \\
\hline 5 & $6.03-2$ & $5.83-2$ & 1.034 \\
\hline 6 & $1.07-1$ & $1.04-1$ & 1.029 \\
\hline 7 & $1.03-1$ & $1.01-1$ & 1.020 \\
\hline 8 & $7.59-2$ & $7.35-2$ & 1.033 \\
\hline 9 & $5.94-2$ & $5.74-2$ & 1.035 \\
\hline 10 & $5.48-2$ & $5.29-2$ & 1.036 \\
\hline 11 & $5.17-2$ & $4.98-2$ & 1.038 \\
\hline 12 & $3.36-2$ & $3.24-2$ & 1.037 \\
\hline 13 & $2.94-2$ & $2.82-2$ & 1.043 \\
\hline 14 & $2.87-2$ & $2.76-2$ & 1.040 \\
\hline 15 & $1.64-2$ & $1.58-2$ & 1.038 \\
\hline 16 & $9.22-3$ & $8.90-3$ & 1.036 \\
\hline 17 & $4.11-3$ & $3.97-3$ & 1.035 \\
\hline 18 & $3.53-3$ & $3.41-3$ & 1.035 \\
\hline 19 & $6.56-3$ & $6.34-3$ & 1.035 \\
\hline 20 & $2.18-2$ & $2.12-2$ & 1.028 \\
\hline 21 & $7.34-3$ & $7.34-3$ & 1.000 \\
\hline 22 & $1.67-2$ & $1.76-2$ & 0.949 \\
\hline 23 & $5.83-2$ & $6.62-2$ & 0.881 \\
\hline 24 & $4.74-2$ & $5.58-2$ & 0.849 \\
\hline 25 & $2.09-2$ & $2.50-2$ & 0.836 \\
\hline 26 & $1.42-2$ & $1.72-2$ & 0.826 \\
\hline 27 & $2.46-3$ & $3.03-3$ & 0.812 \\
\hline
\end{tabular}


Table 8. Comparison of $1-\mathrm{D}$ vs $2-\mathrm{D}$ spectra for top node, Gd assemblies (3.4\% initial enrichment)

\begin{tabular}{|c|c|c|c|}
\hline $\begin{array}{l}\text { Group } \\
\text { no. }\end{array}$ & $\begin{array}{c}\text { Flux } \\
\text { spectrum } \\
\text { (1-D avg) }\end{array}$ & $\begin{array}{c}\text { Flux } \\
\text { spectrum } \\
\text { (2-D avg) }\end{array}$ & $\begin{array}{c}1-D \text { avg/ } \\
2-D \text { avg }\end{array}$ \\
\hline 1 & $6.46-3$ & $6.75-3$ & 0.957 \\
\hline 2 & $5.03-2$ & $4.94-2$ & 1.018 \\
\hline 3 & $6.53-2$ & $6.33-2$ & 1.032 \\
\hline 4 & $4.15-2$ & $4.04-2$ & 1.027 \\
\hline 5 & $6.37-2$ & $6.24-2$ & 1.021 \\
\hline 6 & $1.23-1$ & $1.24-1$ & 0.992 \\
\hline 7 & $1.20-1$ & $1.20-1$ & 1.000 \\
\hline 8 & $8.68-2$ & $8.47-2$ & 1.025 \\
\hline 9 & $6.73-2$ & $6.49-2$ & 1.037 \\
\hline 10 & $6.13-2$ & $5.85-2$ & 1.048 \\
\hline 11 & $5.61-2$ & $5.30-2$ & 1.058 \\
\hline 12 & $3.53-2$ & $3.31-2$ & 1.066 \\
\hline 13 & $3.01-2$ & $2.83-2$ & 1.064 \\
\hline 14 & $2.84-2$ & $2.66-2$ & 1.068 \\
\hline 15 & $1.62-2$ & $1.55-2$ & 1.045 \\
\hline 16 & $9.16-3$ & $8.78-3$ & 1.043 \\
\hline 17 & $4.02-3$ & $3.85-3$ & 1.044 \\
\hline 18 & $3.42-3$ & $3.27-3$ & 1.046 \\
\hline 19 & $6.36-3$ & $6.10-3$ & 1.043 \\
\hline 20 & $2.06-2$ & $1.99-2$ & 1.035 \\
\hline 21 & $6.37-3$ & $6.33-3$ & 1.006 \\
\hline 22 & $1.28-2$ & $1.37-2$ & 0.934 \\
\hline 23 & $3.72-2$ & $4.51-2$ & 0.825 \\
\hline 24 & $2.74-2$ & $3.54-2$ & 0.774 \\
\hline 25 & $1.16-2$ & $1.54-2$ & 0.753 \\
\hline 26 & $7.68-3$ & $1.03-2$ & 0.746 \\
\hline 27 & $1.32-3$ & $1.81-3$ & 0.729 \\
\hline
\end{tabular}


Table 9. Com arison of $1-D$ vs 2-D spectra for top node, non-Gd iissembly (3.4\% initial enrichment)

\begin{tabular}{rccc}
\hline $\begin{array}{c}\text { Group } \\
\text { no. }\end{array}$ & $\begin{array}{c}\text { Flux } \\
\text { spectrum } \\
(1-\mathrm{D} \text { avg })\end{array}$ & $\begin{array}{c}\text { Flux } \\
\text { spectrum } \\
(2-\mathrm{D} \text { avg })\end{array}$ & $\begin{array}{c}1-\mathrm{D} \text { avg } / \\
2-\mathrm{D} \text { avg }\end{array}$ \\
\hline 1 & $5.94-3$ & $6.58-3$ & 0.903 \\
2 & $4.68-2$ & $4.82-2$ & 0.971 \\
3 & $6.14-2$ & $6.17-2$ & 0.995 \\
4 & $3.95-2$ & $3.94-2$ & 1.003 \\
5 & $6.14-2$ & $6.09-2$ & 1.008 \\
6 & $1.21-1$ & $1.21-1$ & 1.000 \\
7 & $1.17-1$ & $1.17-1$ & 1.006 \\
8 & $8.27-2$ & $8.25-2$ & 1.002 \\
9 & $6.34-2$ & $6.33-2$ & 1.002 \\
10 & $5.73-2$ & $5.72-2$ & 1.002 \\
11 & $5.20-2$ & $5.20-2$ & 1.000 \\
12 & $3.25-2$ & $3.25-2$ & 1.000 \\
13 & $2.79-2$ & $2.78-2$ & 1.004 \\
14 & $2.62-2$ & $2.62-2$ & 1.000 \\
15 & $1.55-2$ & $1.55-2$ & 1.000 \\
16 & $8.73-3$ & $8.71-3$ & 1.002 \\
17 & $3.83-3$ & $3.82-3$ & 1.003 \\
18 & $3.25-3$ & $3.24-3$ & 1.003 \\
19 & $6.06-3$ & $6.05-3$ & 1.002 \\
20 & $2.00-2$ & $2.02-2$ & 0.990 \\
21 & $6.56-3$ & $6.56-3$ & 1.000 \\
22 & $1.48-2$ & $1.48-2$ & 1.000 \\
23 & $5.24-2$ & $5.23-2$ & 1.002 \\
24 & $4.15-2$ & $4.15-2$ & 0.994 \\
25 & $1.79-2$ & $1.80-2$ & 1.000 \\
26 & $1.19-2$ & $1.19-2$ & $2.06-3$ \\
27 & $2.05-3$ & & \\
\hline
\end{tabular}


comparison for an assembly without Gd rods. This type of agreement is expected to more closely represent the 1-D to 2-D comparisons over the lifetime of an assembly since the Gd rods typically lose their effect early in the depletion cycle.

Tables 10 and 11 present the spectral differences (fission and absorption fractions) between the top, middle, and bottom nodes. These comparisons are shown to document the large spectral variations in the axial dimension, not to attempt to justify a single-axial-node assumption. The final results reported are for a three-axialnode model with single-axial-node results used for comparative/sensitivity studies. Maximum variations are $20 \%$ to $30 \%$ between the top/middle and middle/bottom comparisons.

\subsection{AXIAL POWER DISTRIBUTION ASSUMPTIONS}

In an operating BWR, the presence of a rapidly changing water density axially giv 's rise to axial power shapes that vary much more than corresponding PWR axial power shapes. This variation is commonly represented by a number of constant power "nodes." The analysis methods used here treat each of these nodes as independent points (i.e., no spatial variation of depletion within the node and no coupling between the nodes). Three equally spaced axial nodes used in this work represent the axial variation (only one radial point was used because the radial variation is less severe). The coupling between the nodes is accomplished by specifying the relative specific powers for each separate node from either the experimentally measured or calculated power distribution. These power distributions also vary with time because of the nonuniform burnup of the fuel. In the absence of experimentally measured power distributione, assumptions as to the time-varying shape of the calculated distributions have to be made. The initial node-specific powers were obtained via a DORT cylindrical (R-Z) model of the BWR assembly described in Tables 2-3 with three different axial water densities. The relative specific power in each of the three axial zones (20.51, 27.35, and 29.84 MW/MTU for top, middle, and bottom nodes) was then input into the SAS2H computations. Because these relative specific powers were for fresh fuel only (and no control rods), their time dependence also needed to be determined.

Several differing assumptions were used to ensure that the final results could be bounded with respect to the shape and time dependence of the relative power distribution. Figure 5 depicts these assumptions. The tailored power assumption shown in Fig. 5a begins with the node-specific powers generated via the $\mathrm{R}-\mathrm{Z}$ model, and then midway through the second cycle the specific powers are equalized for the remainder of the burn cycles. Figure 6 presents a plot of $k_{\infty}$ (obtained at the midpoint of each cycle by SAS2H) versus burnup for this case. The second power shape flat power assumption as shown in Fig. 5b holds the initial specific power in each node constant for the entire burn period. The corresponding $\mathrm{k}_{\infty}$ curves are shown in Fig. 7. The last assumption was to set the specific powers for each node equal, as shown in Fig. 5c. This is an interesting case because in a sense it simulates the effect of control rods (not included previously), which tend to force equal specific powers axially. This simulation is only partial; the spectral effects of the control rods are not modeled, only the tendency of control rods to equalize the power axially by residing in the hottest (bottom) portion of the core. Also, because a single-node analysis must also assume that the specific powers are equal, this case provides an excellent opportunity for multi- to single-node comparisons. Figure 8 shows the node $\mathrm{k}_{\infty}$ trend curves for a constant specific power assumption together with the one-axial-node $\mathrm{k}_{\infty}$ values for comparison. 
Table 10. Comparison of spectral differences (fission fraction by group) in top, middle, and bottom uodes in EWR fuel assembly

\begin{tabular}{|c|c|c|c|c|c|}
\hline $\begin{array}{c}\text { Group } \\
\text { no. }\end{array}$ & $\begin{array}{c}\text { Bottom } \\
\text { node }\end{array}$ & $\begin{array}{l}\text { Middle } \\
\text { node }\end{array}$ & $\begin{array}{c}\text { Top } \\
\text { node }\end{array}$ & $\begin{array}{c}\text { Bottom/ } \\
\text { middle }\end{array}$ & $\begin{array}{l}\text { Top/ } \\
\text { middle }\end{array}$ \\
\hline 1 & $5.27-3$ & $6.11-3$ & $6.60-3$ & 0.86 & 1.08 \\
\hline 2 & $1.87-2$ & $2.26-2$ & $2.49-2$ & 0.83 & 1.10 \\
\hline 3 & $2.02-2$ & $2.51-2$ & $2.82-2$ & 0.81 & 1.12 \\
\hline 4 & $8.41-3$ & $1.06-2$ & $1.21-2$ & 0.79 & 1.14 \\
\hline 5 & $2.54-3$ & $3.31-3$ & $3.84-3$ & 0.77 & 1.16 \\
\hline 6 & $2.28-3$ & $3.17-3$ & $3.83-3$ & 0.72 & 1.21 \\
\hline 7 & $2.29-3$ & $3.20-3$ & $3.90-3$ & 0.72 & 1.22 \\
\hline 8 & $2.35-3$ & $3.25-3$ & $3.89-3$ & 0.72 & 1.20 \\
\hline 9 & $3.25-3$ & $4.44-3$ & $5.26-3$ & 0.73 & 1.18 \\
\hline 10 & $6.93-3$ & $9.37-3$ & $1.10-2$ & 0.74 & 1.17 \\
\hline 11 & $1.44-2$ & $1.90-2$ & $2.19-2$ & 0.76 & 1.15 \\
\hline 12 & $1.86-2$ & $2.34-2$ & $2.63-2$ & 0.79 & 1.12 \\
\hline 13 & $1.74-2$ & $2.14-2$ & $2.37-2$ & 0.81 & 1.11 \\
\hline 14 & $1.33-2$ & $1.59-2$ & $1.73-2$ & 0.84 & 1.09 \\
\hline 15 & $3.46-3$ & $4.32-3$ & $4.88-3$ & 0.80 & 1.13 \\
\hline 16 & $2.31-3$ & $2.88-3$ & $3.27-3$ & 0.80 & 1.14 \\
\hline 17 & $3.50-3$ & $4.34-3$ & $4.88-3$ & 0.81 & 1.12 \\
\hline 18 & $4.67-3$ & $5.73-3$ & $6.40-3$ & 0.82 & 1.12 \\
\hline 19 & $5.69-3$ & $7.00-3$ & $7.84-3$ & 0.81 & 1.12 \\
\hline 20 & $2.49-2$ & $3.02-2$ & $3.35-2$ & 0.82 & 1.11 \\
\hline 21 & $1.56-2$ & $1.79-2$ & $1.93-2$ & 0.87 & 1.08 \\
\hline 22 & $4.86-2$ & $5.23-2$ & $5.43-2$ & 0.93 & 1.04 \\
\hline 23 & $2.00-1$ & $1.98-1$ & $1.97-1$ & 1.01 & 0.99 \\
\hline 24 & $2.46-1$ & $2.29-1$ & $2.20-1$ & 1.07 & 0.96 \\
\hline 25 & $1.45-1$ & $1.32-1$ & $1.24-1$ & 1.10 & 0.94 \\
\hline 26 & $1.32-1$ & $1.16-1$ & $1.06-1$ & 1.14 & 0.91 \\
\hline 27 & $3.48-2$ & $3.05-2$ & $2.72-2$ & 1.14 & 0.89 \\
\hline
\end{tabular}

${ }^{a}$ Read as $5.27 \times 10^{-3}$. 
Table 11. Comparison of spectral differences (absorption fraction by group) in top, middle, and bottom nodes in BWR fuel assembly

\begin{tabular}{cccccc}
\hline $\begin{array}{c}\text { Group } \\
\text { no. }\end{array}$ & $\begin{array}{c}\text { Bottom } \\
\text { node }\end{array}$ & $\begin{array}{c}\text { Middle } \\
\text { node }\end{array}$ & $\begin{array}{c}\text { Top } \\
\text { node }\end{array}$ & $\begin{array}{c}\text { Bottom/ } \\
\text { middle }\end{array}$ & $\begin{array}{c}\text { Top/ } \\
\text { middle }\end{array}$ \\
\hline 1 & $3.05-3^{a}$ & $3.31-3$ & $3.45-3$ & 0.92 & 1.04 \\
2 & $1.13-2$ & $1.30-2$ & $1.39-2$ & 0.87 & 1.07 \\
3 & $1.12-2$ & $1.37-2$ & $1.52-2$ & 0.82 & 1.11 \\
4 & $5.38-3$ & $6.72-3$ & $7.57-3$ & 0.80 & 1.13 \\
5 & $3.37-3$ & $4.32-3$ & $4.95-3$ & 0.78 & 1.15 \\
6 & $5.14-3$ & $7.01-3$ & $8.35-3$ & 0.73 & 1.20 \\
7 & $5.48-3$ & $7.55-3$ & $9.05-3$ & 0.73 & 1.20 \\
8 & $9.25-3$ & $1.26-2$ & $1.48-2$ & 0.73 & 1.17 \\
9 & $1.58-2$ & $2.11-2$ & $2.46-2$ & 0.75 & 1.17 \\
10 & $2.35-2$ & $3.01-2$ & $3.39-2$ & 0.78 & 1.13 \\
11 & $3.87-2$ & $4.78-2$ & $5.25-2$ & 0.81 & 1.10 \\
12 & $4.17-2$ & $4.95-2$ & $5.29-2$ & 0.84 & 1.07 \\
13 & $3.86-2$ & $4.49-2$ & $4.75-2$ & 0.86 & 1.06 \\
14 & $5.27-2$ & $4.88-2$ & $6.05-2$ & 0.90 & 1.03 \\
15 & $5.94-3$ & $7.04-3$ & $7.75-3$ & 0.84 & 1.10 \\
16 & $3.34-3$ & $3.94-3$ & $4.32-3$ & 0.85 & 1.19 \\
17 & $3.44-3$ & $4.10-3$ & $4.51-3$ & 0.84 & 1.10 \\
18 & $3.88-3$ & $4.60-3$ & $5.03-3$ & 0.84 & 1.09 \\
19 & $4.95-3$ & $5.83-3$ & $6.36-3$ & 0.85 & 1.09 \\
20 & $2.14-2$ & $2.49-2$ & $2.70-2$ & 0.86 & 1.08 \\
21 & $1.29-2$ & $1.44-2$ & $1.51-2$ & 0.90 & 1.05 \\
22 & $4.10-2$ & $4.27-2$ & $4.34-2$ & 0.96 & 1.02 \\
23 & $1.71-1$ & $1.63-1$ & $1.59-1$ & 1.05 & 0.98 \\
24 & $2.06-1$ & $1.86-1$ & $1.75-1$ & 1.11 & 0.94 \\
25 & $1.20-1$ & $1.06-1$ & $9.77-2$ & 1.13 & 0.92 \\
26 & $1.10-1$ & $9.44-2$ & $8.46-2$ & 1.17 & 1.18 \\
\hline & $3.03-2$ & $2.57-2$ & $2.26-2$ & & 0.90 \\
\hline
\end{tabular}

${ }^{a}$ Read as $3.05 \times 10^{-3}$. 
OPV owo sourean
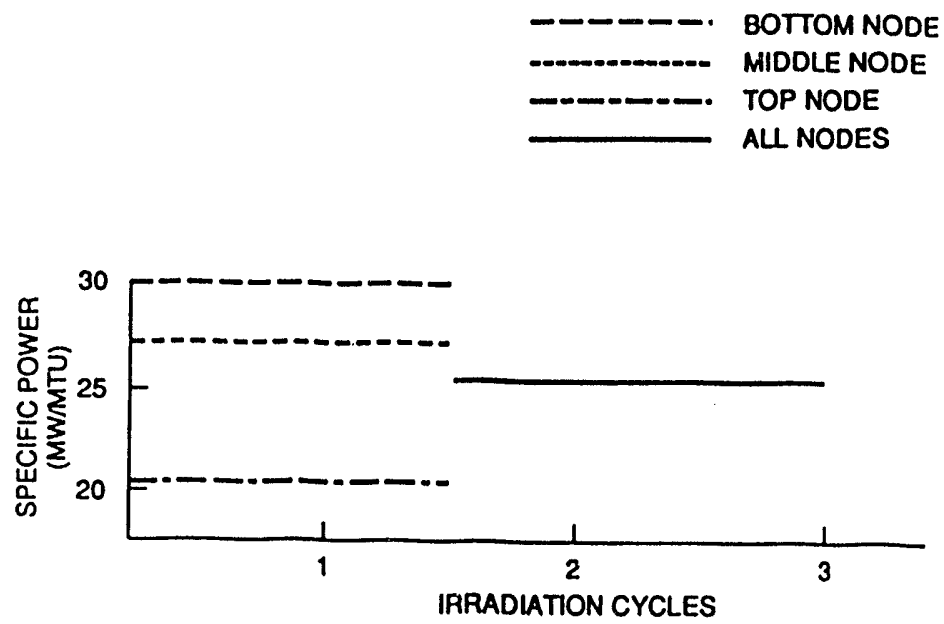

(a) TAILORED POWER ASSUMPTION

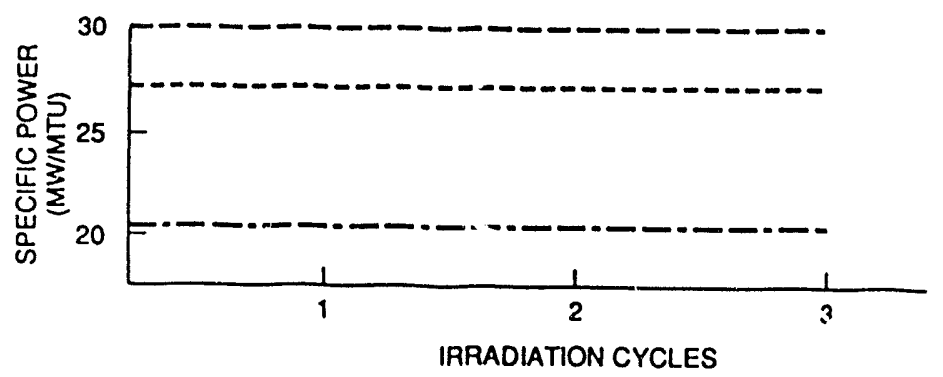

(b) FLAT POWER ASSUMPTION

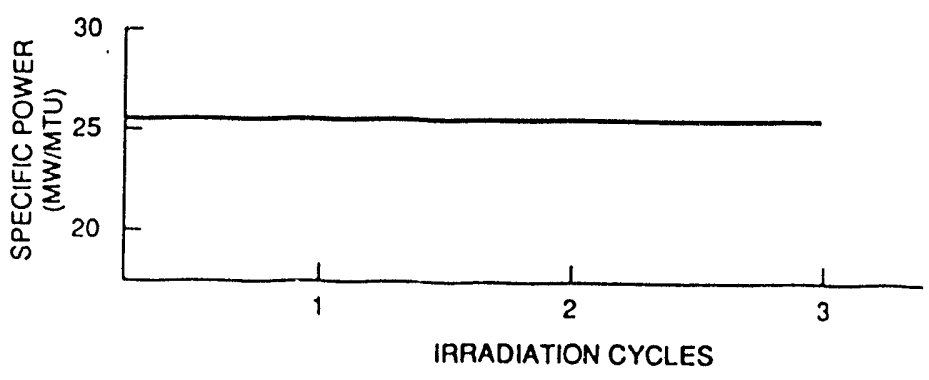

(c) CONSTANT POWER ASSUMPTION

Fig. 5. Assumed axial power distributions. 


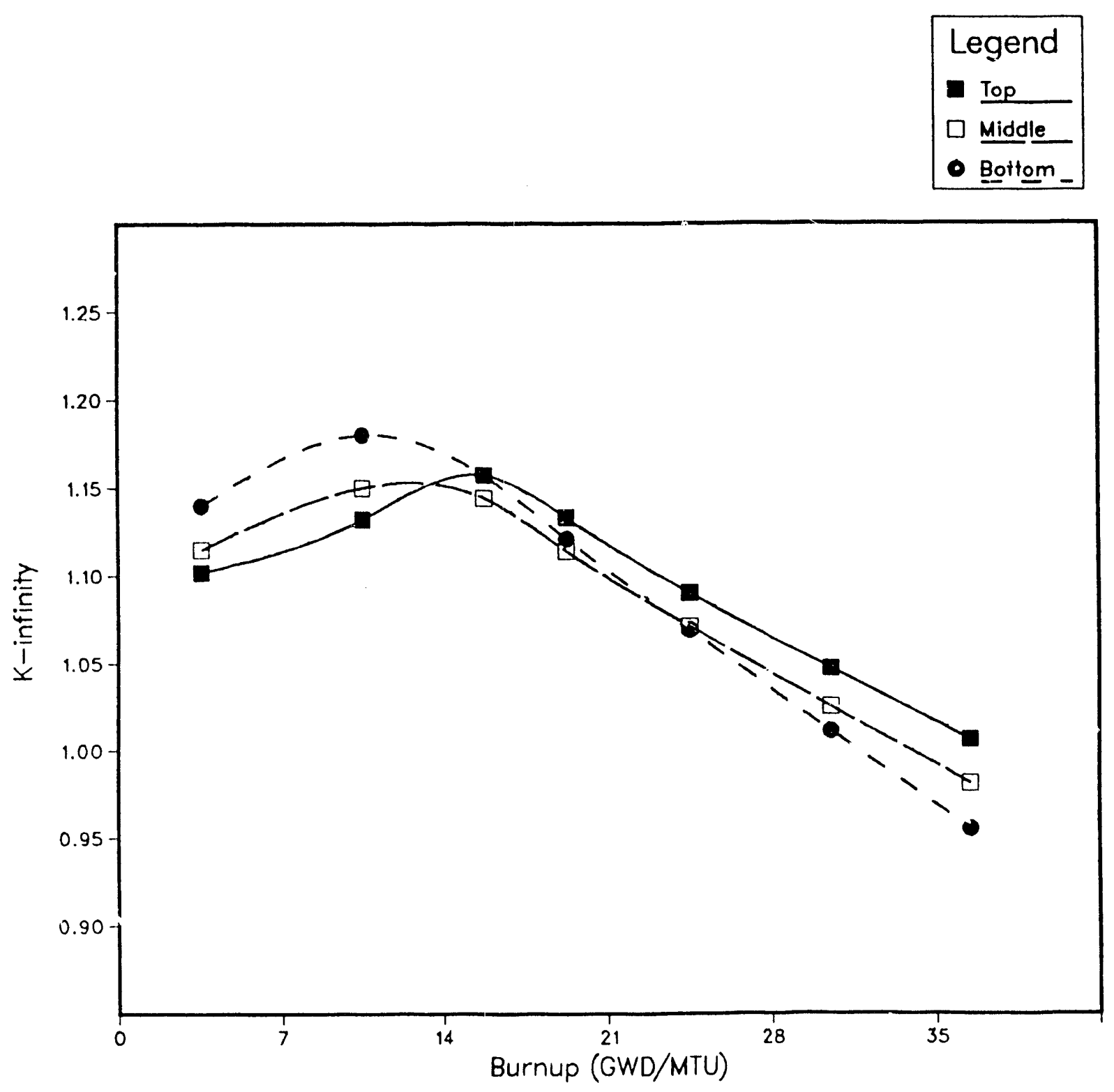

Fig. 6. $k_{\infty}$ versus burnup for tailored axial power assumptions. 


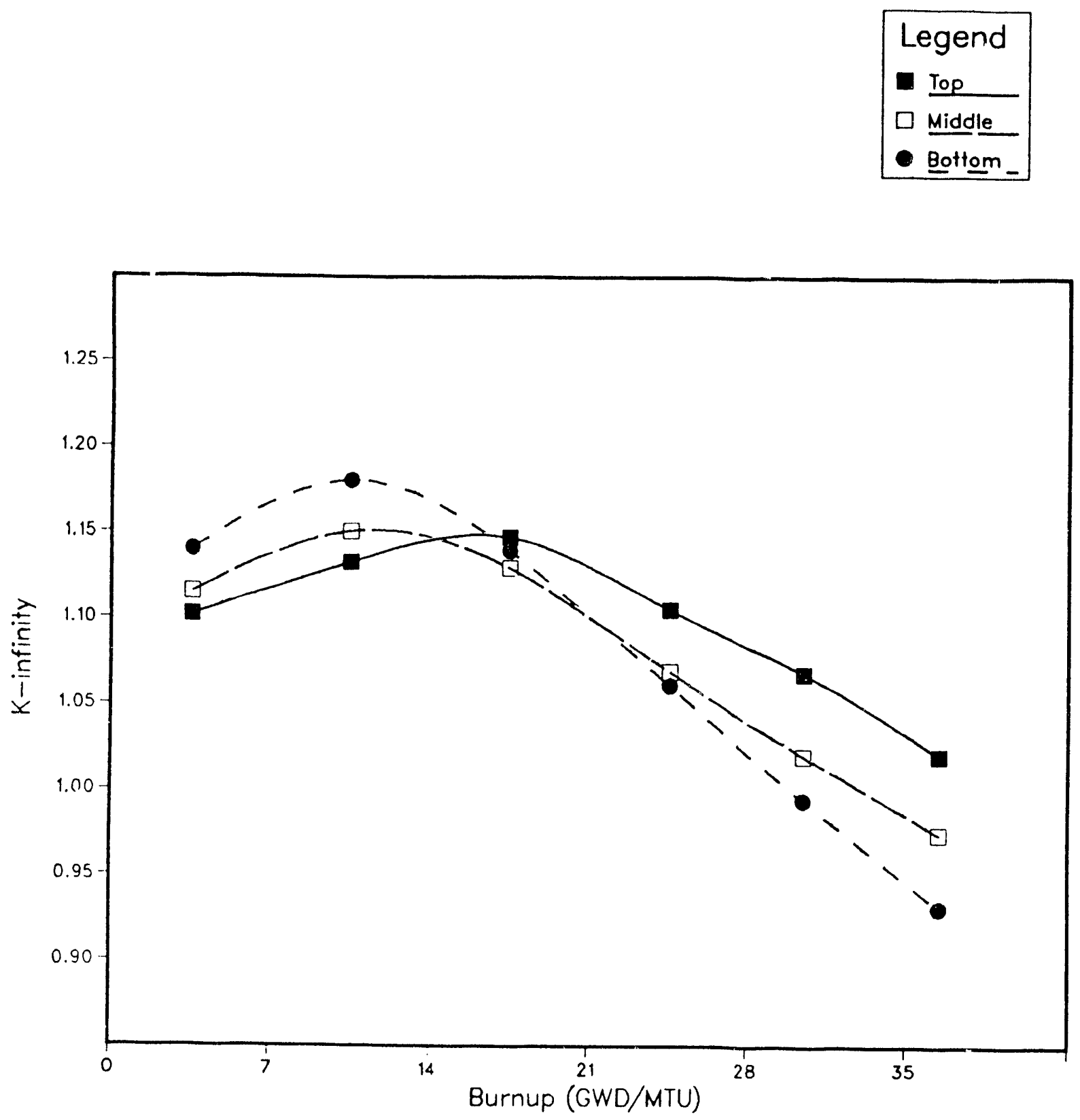

Fig. 7. $k_{\infty}$ versus burnup for flat axial power assumptions. 


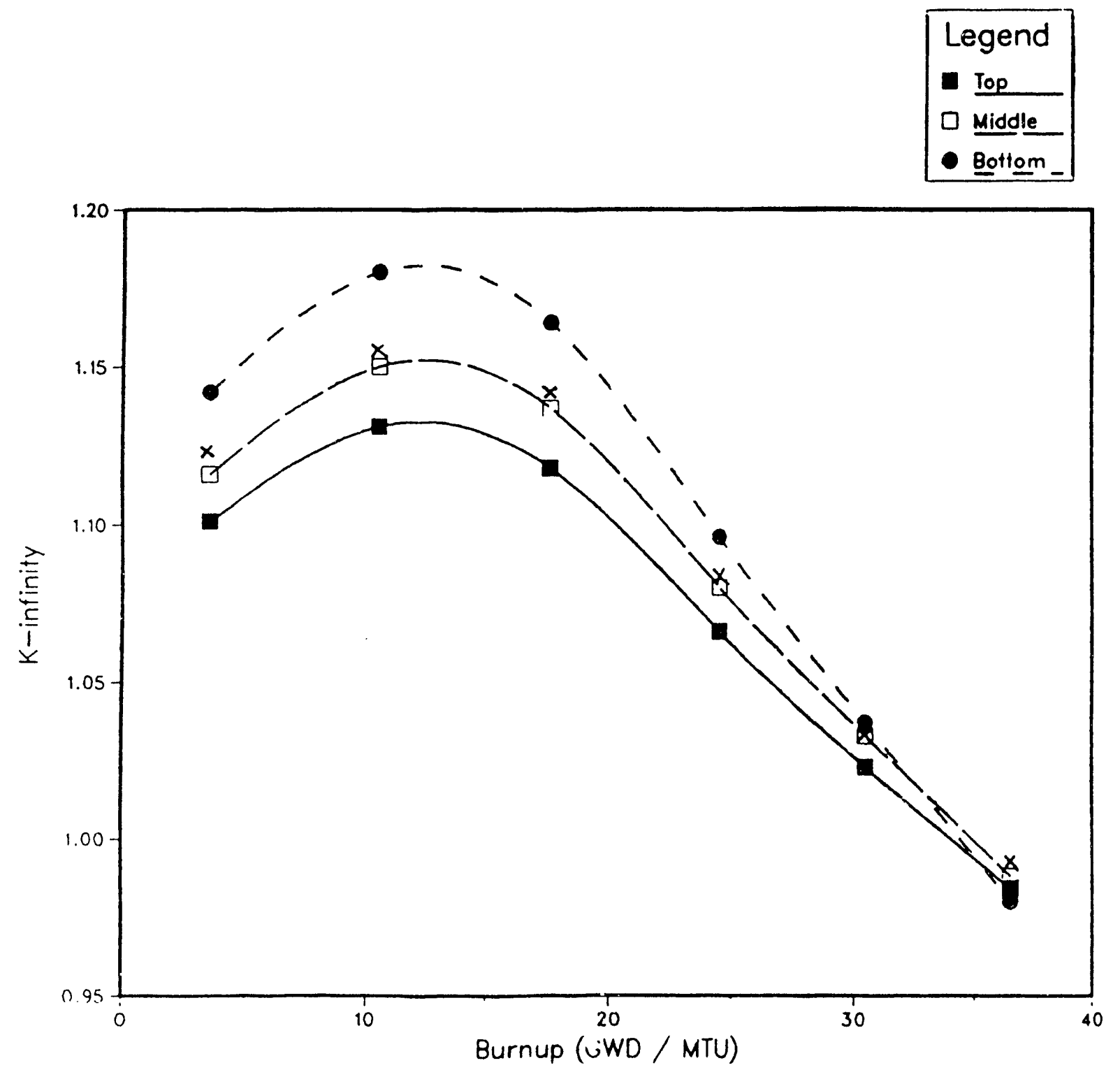

Fig. 8. $k_{\infty}$ versus burnup for constant axial power assumption and one-axial-node case (denoted by $\mathbf{x}$ ). 
The three cases shown in Figs. 6-8 all begin with identical values. The various assumptions on the specific powers, however, produce results that vary considerably over the burn time of the assembly. Clearly, end-of-life reactivity differences of nearly $10 \%$ between the bottom and top nodes in Fig. 7 would be unacceptable in an operating reactor because of both control problems and fuel economy considerations. The tailored power assumption reduced the final reactivity difference to about $5 \%$, with little more improvement expected by varying the location where the powers were equalized. Thus, this specific power strategy was used for the calculation of spent fuel isotopics for the remaining enrichments (see Sect. 5 for further discussion). The $\mathrm{k}_{\infty}$ trends for the constant power assumption give nearly identical ending reactivities. This method should give an estimate of the effects of control rods on the final results and will be used as an indicator of the spread in the results, because both the constant and tailored methods appear equally good. Two criteria determined the selection of these two methods: (1) the end-of-life reactivities had to be very nearly the same for each node (for fuel economy considerations); (2) the reactivities for each axial node had to be similar over the last half of the assembly lifetime (for reactor control considerations).

The one-axial-node $k_{\infty}$ values in Fig. 8 agree closely with the middle node of the constant three-axial-node case. The isotopics from this case will also be included in the final results to possibly indicate a bounding estimate for the endof-life reactivities and control requirements.

\subsection{AXIAL ISOTOPIC VARIATIONS}

Using these various axial power distribution assumptions, predictions of the ending isotopic concentrations were produced for BWR fuel with an initial average ${ }^{235} \mathrm{U}$ enrichment of $3.4 \%$ undergoing a $40-\mathrm{GWd} / \mathrm{MTU}$ burnup. One question posed was how much variation in the isotopics would be produced by the various power distribution assumptions. Tables 12 and 13 give results for two such comparisuns, first for a one-axial-node versus a three-axial-node case (tailored case), followed by a flat versus tailored comparison. Table 12 shows that the one-node values generally agree with the average of the isotopics from each of the three nodes. Therefore, if the desired quantities are average concentrations over the entire assembly, the oneaxial-node assumption should yield reasonable results. Large differences are seen between fissile concentrations in the top node and the one-axial-node values (i.e., $2.051 \times 10^{-4}$ versus $1.556 \times 10^{-4}$ for $\left.{ }^{235} \mathrm{U}\right)$. Because of the inherent voiding in the upper levels of a BWR core, moderation in the top portion is much less than in the bottom portion. Therefore, the fuel reactivity distribution during reactor operation is only mildly sensitive to the large axial variations seen in Table 12 , because the lower moderation near the top has a tendency to cancel the effects of the larger fissile material concentrations in the top node.

In a shipping or storage cask filled with full-density water, quite a different situation exists. There the higher fissile concentrations in the top node can cause the predicted reactivities to be dominated by the top effects. A similar pattern is seen in Table 13, in which the isotopics predicted by the flat and tailored power approximations are compared. Again the ratio of the averages is near 1, but a comparison of the two top node ${ }^{235} \mathrm{U}$ concentrations (tailored values given in Table 12 with the flat values in Table 13) shows about a $20 \%$ difference. This noteworthy difference shows the importance of the power distribution assumption in predicting the cask reactivities. The reactivity effects of the various power assumptions in shipping or storage cask environments are examined in Sect. 5. 
Table 12. One-node vs three-node isotopic comparison (atoms/b-cm) at end of $40 \mathrm{GWd} / \mathrm{MTU}$ for 3.4\% initially enriched BWR fuel

\begin{tabular}{lcccccc}
\hline Nuclide & Top $^{a}$ & Middle $^{a}$ & Bottom $^{a}$ & $\begin{array}{c}\text { 3-node } \\
\text { average }\end{array}$ & 1 node & $\begin{array}{c}\text { 3 node/ } \\
1 \text { node }\end{array}$ \\
\hline${ }^{235} \mathrm{U}$ & $2.091-4$ & $1.573-4$ & $1.142-4$ & $1.602-4$ & $1.556-4$ & $1.03-0$ \\
${ }^{238} \mathrm{U}$ & $2.072-2$ & $2.067-2$ & $2.071-2$ & $2.070-2$ & $2.071-2$ & $1.00-0$ \\
${ }^{239} \mathrm{Pu}$ & $1.301-4$ & $1.151-4$ & $8.930-5$ & $1.115-4$ & $1.066-4$ & $1.0-46$ \\
${ }^{241} \mathrm{Pu}$ & $2.996-5$ & $2.963-5$ & $2.429-5$ & $2.796-5$ & $2.729-5$ & $1.0-25$ \\
${ }^{133} \mathrm{Cs}$ & $4.548-5$ & $5.076-5$ & $5.346-5$ & $4.990-5$ & $5.006-5$ & $0.9-97$ \\
${ }^{143} \mathrm{Nd}$ & $3.117-5$ & $3.245-5$ & $3.087-5$ & $3.150-5$ & $3.160-5$ & $0.9-97$ \\
${ }^{244} \mathrm{Cm}$ & $6.030-7$ & $8.706-7$ & $7.918-7$ & $7.551-7$ & $7.187-7$ & $1.0-51$ \\
\hline
\end{tabular}

assumes tailored case power densities.

Table 13. Effect of flat vs tailored specific power burnup assumption on isotopic compositions (atoms/b-cm) at end of $40 \mathrm{GWd} / \mathrm{MTU}$ for $3.4 \%$ initial enrichment BWR fuel

\begin{tabular}{|c|c|c|c|c|c|c|}
\hline Nuclide & Top ${ }^{a}$ & Middle $^{a}$ & Bottom ${ }^{a}$ & $\begin{array}{c}\text { Flat }(F) \\
\text { 3-node } \\
\text { average }\end{array}$ & $\begin{array}{c}\text { Tailored }(\mathrm{T}) \\
\text { 3-node } \\
\text { average }\end{array}$ & $\mathrm{F} / \mathrm{T}$ \\
\hline${ }^{235} \mathrm{U}$ & $2.53-4$ & $1.48-4$ & $9.14-5$ & $1.64-4$ & $1.60-4$ & 1.03 \\
\hline${ }^{238} \mathrm{U}$ & $2.08-2$ & $2.07-2$ & $2.07-2$ & $2.07-2$ & $2.07-2$ & 1.00 \\
\hline${ }^{239} \mathrm{Pu}$ & $1.27-4$ & $1.15-4$ & $8.85-5$ & $1.10-4$ & $1.12-4$ & 0.98 \\
\hline${ }^{241} \mathrm{Pu}$ & $2.59-5$ & $3.03-5$ & $2.54-5$ & $2.72-5$ & $2.80-5$ & 0.97 \\
\hline${ }^{133} \mathrm{Cs}$ & $4.04-5$ & $5.20-5$ & $5.67-5$ & $4.97-5$ & $4.99-5$ & 1.00 \\
\hline${ }^{143} \mathrm{Nd}$ & $2.86-5$ & $3.29-5$ & $3.13-5$ & $3.09-5$ & $3.15-5$ & 0.98 \\
\hline${ }^{244} \mathrm{Cm}$ & $3.26-7$ & $9.98-7$ & $1.15-6$ & $8.25-7$ & $7.55-7$ & 1.09 \\
\hline
\end{tabular}

a Assumes flat case power densities. 


\section{REACTIVITY PREDICTIONS}

The isotopics reported to this point were obtained for a single initial average enrichment of $3.4 \%$ and have not included any decay after removal from the reactor. This section presents the results of a parametric study performed using the methods described earlier. The initial enrichments evaluated included $2.5 \%, 2.9 \%, 3.4 \%$, and $3.8 \%$. These correspond to an average enrichment over the entire BWR fuel element. Isotopic concentrations were obtained at the end of each cycle for each of the initial enrichments. For $3.8 \%$ initial enrichment the burnups steps were $7,14,21,28,33$, 40 , and $45 \mathrm{GWd} / \mathrm{MTU}$; maximum burnups were 40,33 , and $28 \mathrm{GWd} / \mathrm{MTU}$ for the $3.4 \%, 2.9 \%$, and $2.5 \%$ enrichments, respectively. At each of the time steps, the isotopic information was expanded to include cooling times of $1,2,5,10,15$, and 20 years. In all cases, the isotopic information was penerated using SAS2H assuming a tailored power distribution, as discussed in Sect. 4. This isotopic information was then input into a KENO V.a criticality calculation for an infinite array of assemblies. Sensitivity analyses were conducted to determine the effects of the various power distribution assumptions on end-of-cycle fuel isotopic predictions. In all these cases the burnable poison (Gd) was assumed to be totally depleted.

\subsection{REACTIVITY TREND CURVES}

Figures 9-12 depict the reactivities resulting from the above-described parametric study for initial average enrichments of $2.5 \%, 2.9 \%, 3.4 \%$, and $3.8 \%$. The prominent features of the curves include:

1. the obvious decrease of reactivity with increasing burnup;

2. the decrease of reactivity with increased cooling time, primarily because of the decay of ${ }^{241} \mathrm{Pu}$;

3. the enhancement of effect (2) with further burnup because of the increased production of ${ }^{241} \mathrm{Pu}$ with burnup and the subsequent decay during cooling; and

4. the enhancement of effect (2) for smaller enrichments given identical burnups as a result of increased ${ }^{241} \mathrm{Pu}$ production because of the larger initial ${ }^{238} \mathrm{U}$ inventory.

Examination of Figs. 9-12 reveals an overall decrease in $\mathrm{k}_{\infty}$ from fresh to fully spent fuel of 30 to $40 \% \Delta \mathrm{k}, 5$ to $10 \%$ because of the reactivity loss during cooling. These reactivity changes are very similar to the PWR results given in ref. 1 , where overall reactivity decreases are in the $30-40 \% \Delta \mathrm{k}$ range for comparable burnups.

As stated previously, the curves in Figs. 9-12 were generated assuming a tailored axial power variation. Figure 13 gives similar trend curves for each of the various power distribution assumptions for fully burned (40-GWd/MTU) $3.4 \%$ initial enrichment fuel. These curves illustrate the sensitivity of the final isotopic results to the time-varying power distributions. The extremes of the four cases are the flat (see Fig. 5) and the average power (single axial node) assumptions. These assumptions result in reactivity predictions of nearly $10 \% \Delta \mathrm{k}$. The flat assumption is unreasonable from a physical viewpoint because the wide variation in reactivity from top to bottom could not be tolerated operationally. The single axial mode approach suffers from calculational inadequacies because the axial variation in power cannot be explicitly treated. The other two assumptions are more plausible (based primarily on reactivity traces shown in Figs. 6 and 8) and produce reactivity predictions that differ by only $2-3 \% \Delta \mathrm{k}$. The tailored assumption was used in this 


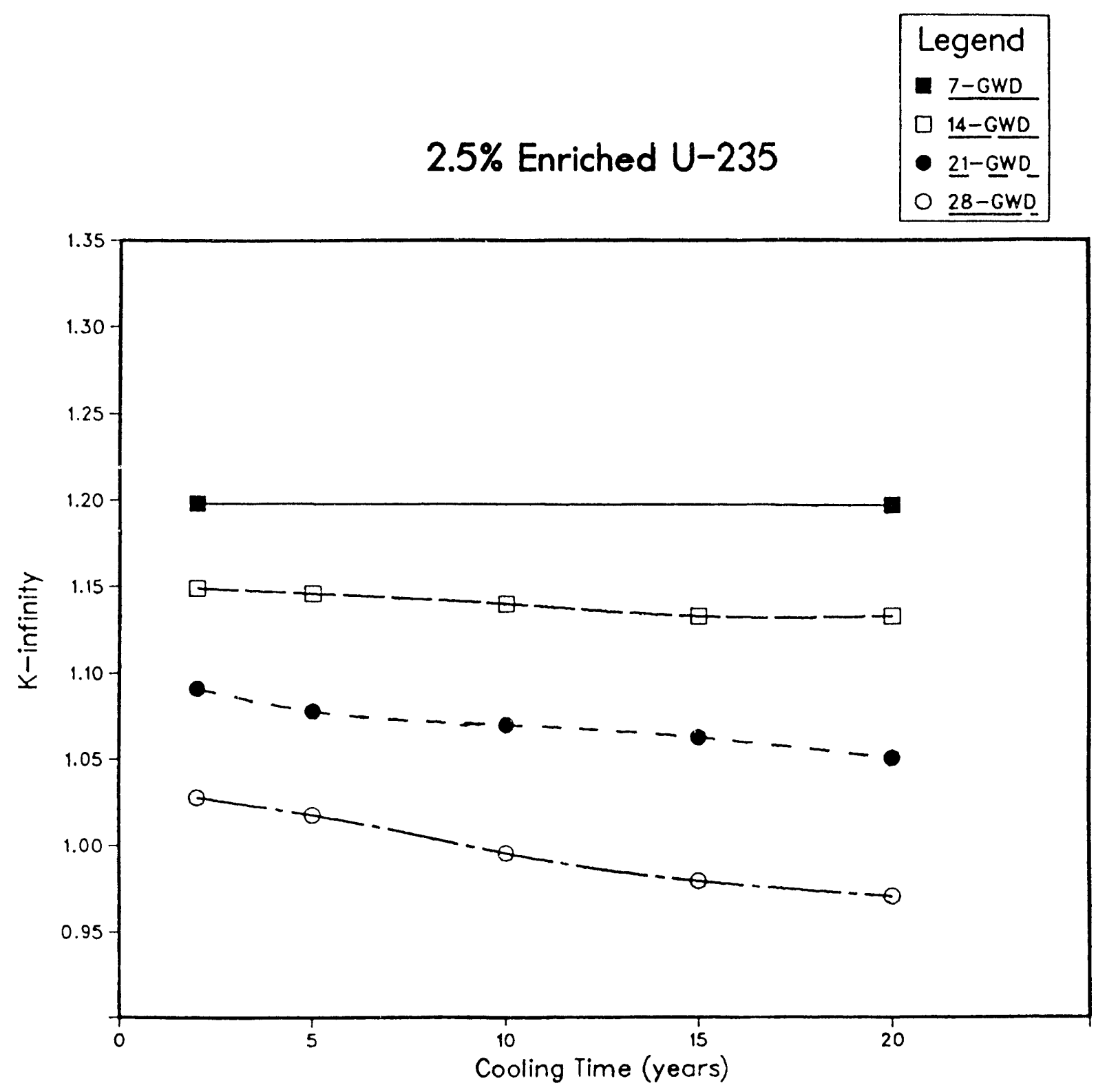

Fig. 9. $k_{\infty}$ as a function of burnup and cooling time for $2.5 \mathrm{wt} \%$ initial enrichment fuel. 

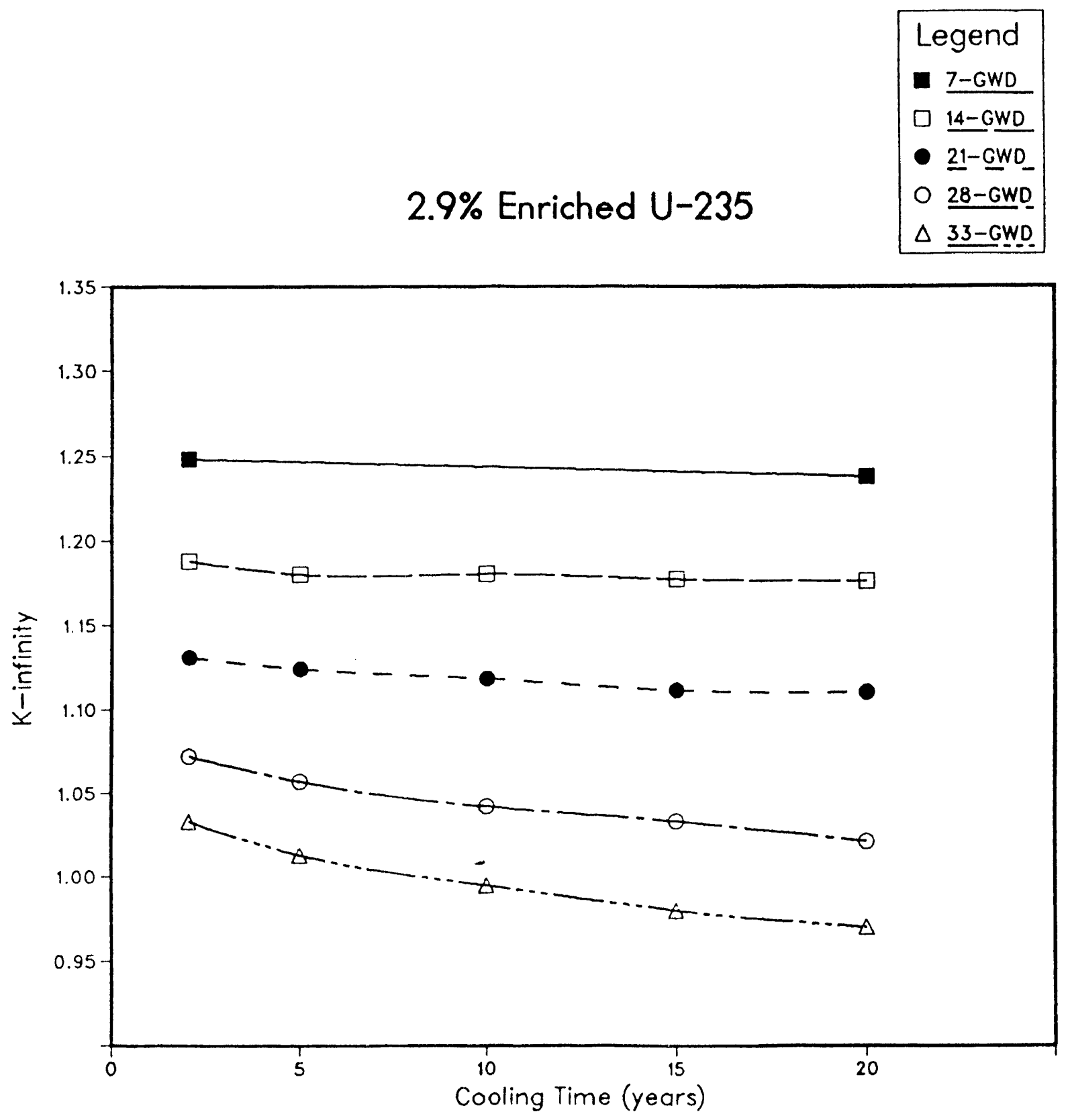

Fig. 10. $k_{\infty}$ as a function of burnup and cooling time for 2.9 wt $\%$ initial enrichment fuel. 


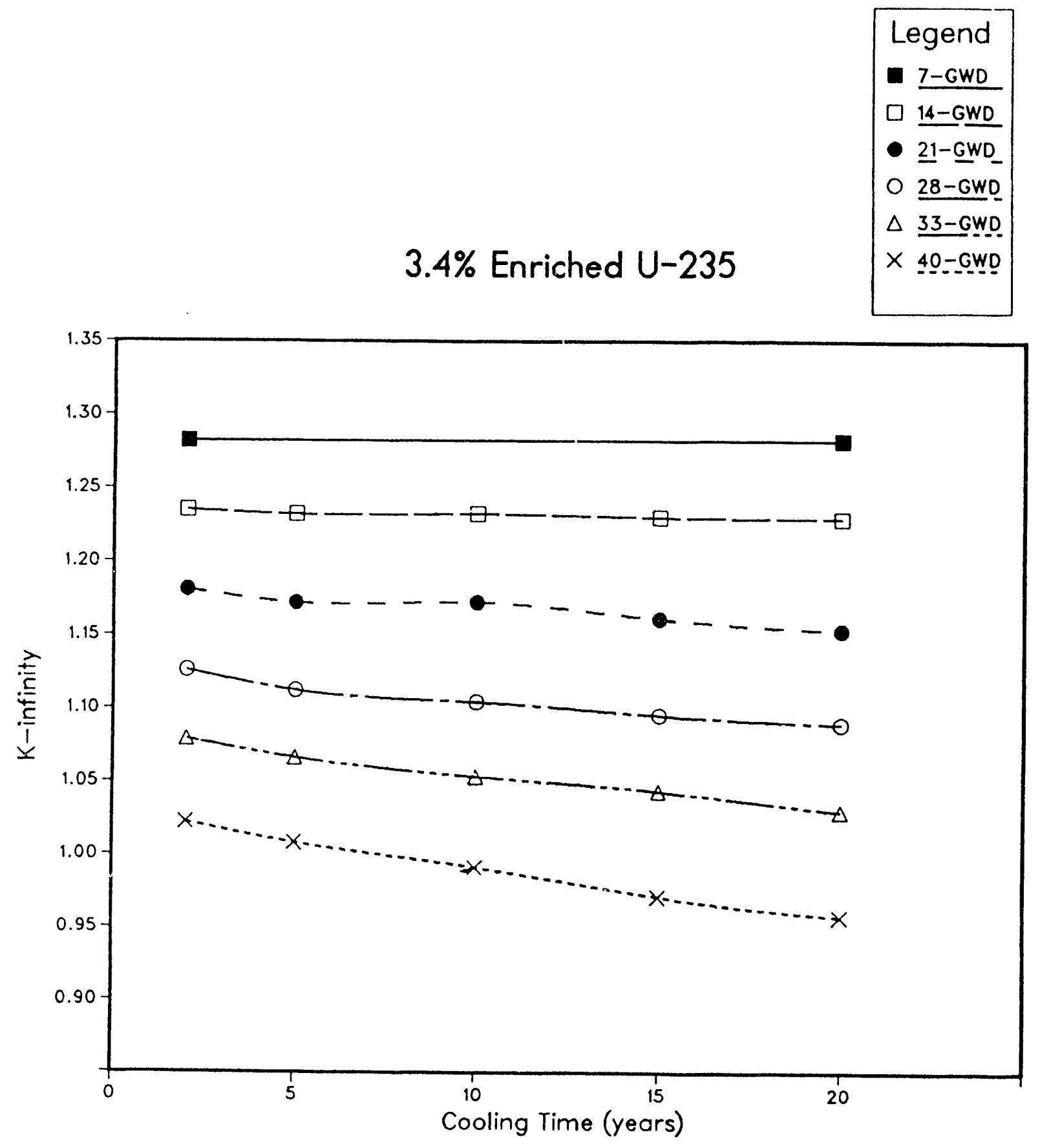

Fig. 11. $k_{\infty}$ as a function of burnup and cooling time for $3.4 \mathrm{wt} \%$ initial enrichment fuel. 

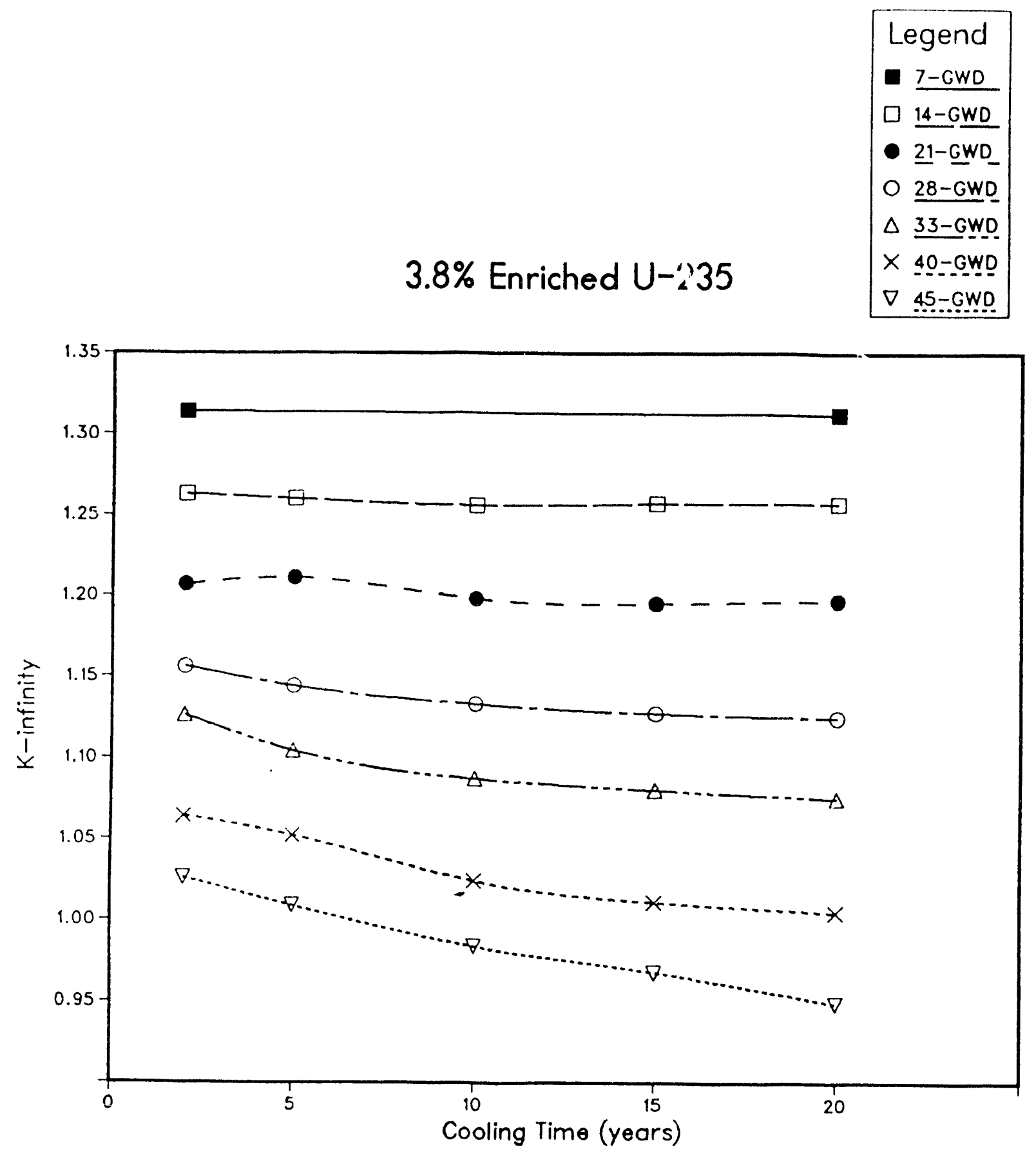

Fig. 12. $k_{\infty}$ as a function of burnup and cooling time for 3.8 wt $\%$ initial enrichment fuel. 

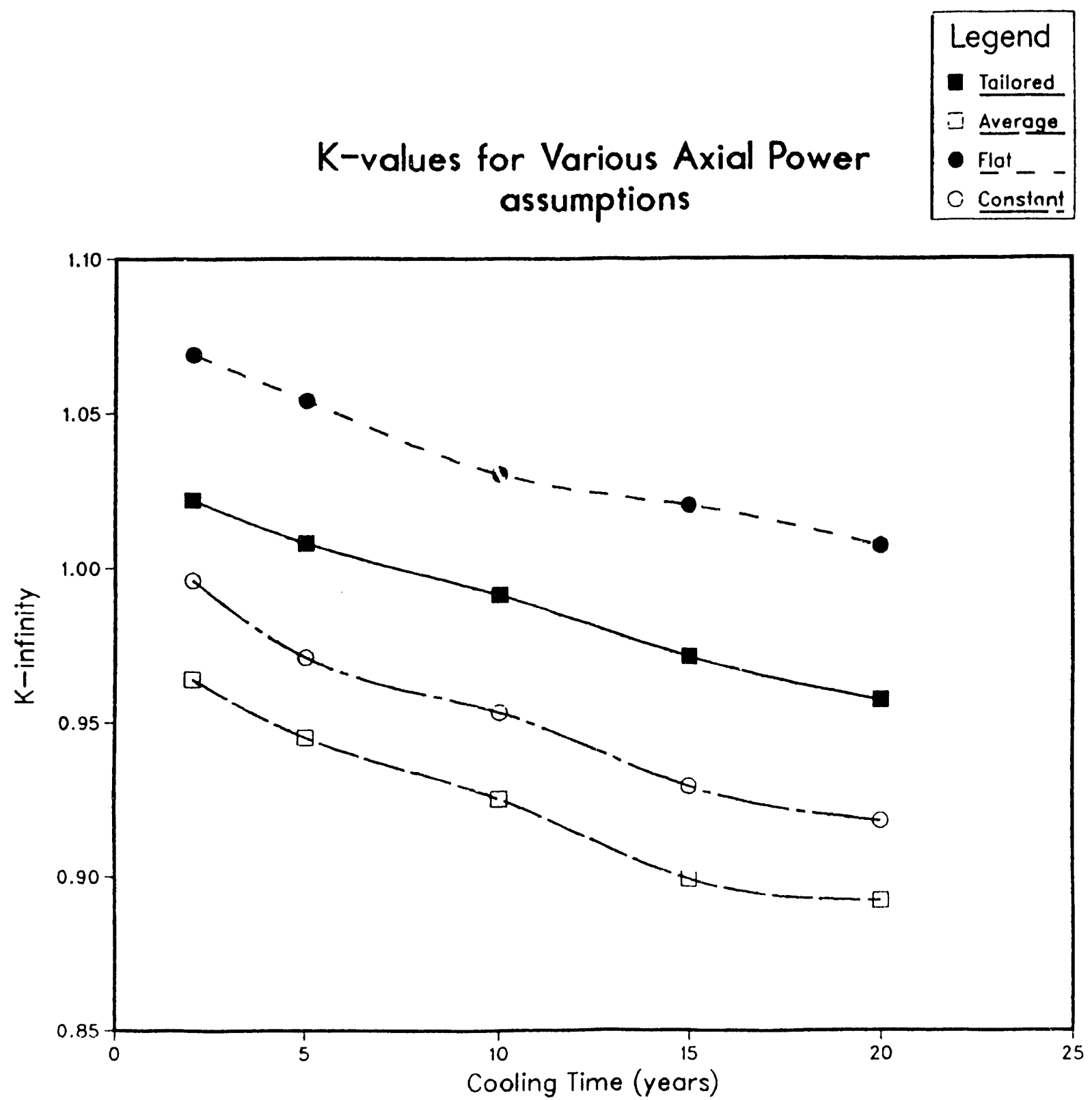

Fig. 13. $k_{\infty}$ values for various axial power assumptions for $3.4 \%$ initial enrichment at the end of $40-G W d / M T U$ burnup. 
analysis; however, either assumption would have been equally appropriate for an investigation of burnup credit feasibility.

\subsection{CONTROL REQUIREMENTS}

The reactivity trend curves presented in Figs. 9-i2 were generated assuming an infinite array of assemblies at the given burnup and cooling times, separated by water only. These reactivity values allow the determination of the control requirements of a basket material to maintain the reactivity of the overall shipping cask at a certain preset limit. The control requirements given in Table 14 are appropriate for two-year-cooled fuel at the specified burnups and initial enrichments. These values were obtained by taking the difference between the two-year-cooled values in Figs. 9-12 and 0.93. The two-year cooling time was chosen to give a minimal reactivity loss because of the ${ }^{241} \mathrm{Pu}$ and fission produst decay. The value of 0.93 was chosen to be a typical licensable value for a shipping cask when analyzed with the SCALE methodology. An added conservatism was the neglect of the leakage from the cask, which has been estimated ${ }^{8}$ to be approximately $3 \%$ for a large rail cask and $9 \%$ for smaller truck casks. The control requirements range from a near constant 0.10 at the end-of-cycle to 0.50 for the highest enrichment fresh fuel. The trends seen here are slowly increasing control requirements with initial enrichment and rapidly decreasing control requirements with burnup. By comparing these control requirements to the basket worths for various possible basket designs, the range of applicability of each basket is readily determined.

\subsection{BASKET WORTHS}

The basket web evaluated was a composite boral/SS-304 taken from ref. 1 (see Fig. 14). The web thickness was initially set at 0.5 in., with the thicknesses of stainless steel and boral as given in Fig. 14. Additional web designs studied were for a 0.25 -in. web with the same relative thicknesses of boral and SS-304 as the 0.5 -in. web. A final web design used only SS-304 to determine to what extent a non-borated basket could be used.

The basket worths given in Table 15 show that the 0.5 -in. boral/SS-304 web and the 0.25 -in. boral/SS-304 web are sufficient to meet the control requirements of fresh fuel up to $4.5 \%$ initial enrichment. Even higher enrichments are possible because the basket worths reported in the table are for an infinite array of assemblies; thus no credit has been included for leakage from the cask.

An interesting comparison can be made with the results presented in Table 15 for BWRs to those in ref. 8 for PWRs. While the control requirement (CR) values are very similar, 0.50 for fresh $4.5 \%$ enriched BWR fuel to 0.52 for $4.5 \%$ enriched PWR fuel, the basket worths are very different. The basket worth for an identical basket web (0.5 in. boral/SS-304) was 0.32 for fresh $3.75 \%$ enriched PWR fuel versus 0.54 for fresh $3.8 \%$ enriched BWR fuel. The near doubling of basket worths for BWR assemblies can be understood by comparing typical $\mathrm{k}_{\text {ef } f}$ values for single $\mathrm{BWR}\left(\mathrm{k}_{\text {eff }} \approx 0.7\right)$ and $\mathrm{PWR}\left(\mathrm{k}_{\text {eff }} \approx 0.9\right)$ assemblies. With much lower reactivities, BWR assemblies are much more dependent upon assembly-toassembly coupling. Thus, the boral/SS-304 plates are much more effective for the lower reactivity BWR fuel elements than for the corresponding PWR assemblies. A SS-304-only, 0.5-in. thickness basket web was also considered to indicate the relative worths of poisoned versus unpoisoned webs of the same thickness. The SS-304-only web does not meet the control requirements of $3.8 \%$ enriched fuel, unless burnup credit is used (from Table 14, a burnup of approximately $40 \mathrm{GWd} / \mathrm{MTU}$ is needed to match control requirements with the basket worth). 
Table 14. Control requirements after two-year cooling times

\begin{tabular}{cccccc}
\hline Burnup & \multicolumn{5}{c}{ Initial enrichments (\%) } \\
(GWd/M'rU) & 2.5 & 2.9 & 3.4 & 3.8 & 4.5 \\
\hline 0 & 0.35 & 0.39 & 0.44 & 0.45 & 0.50 \\
7 & 0.27 & 0.32 & 0.35 & 0.38 & - \\
14 & 0.22 & 0.26 & 0.31 & 0.33 & - \\
21 & 0.16 & 0.20 & 0.25 & 0.28 & - \\
28 & 0.10 & 0.14 & 0.20 & 0.23 & - \\
33 & - & 0.10 & 0.15 & 0.20 & - \\
40 & - & - & 0.09 & 0.13 & - \\
45 & - & - & - & 0.10 & - \\
\hline
\end{tabular}

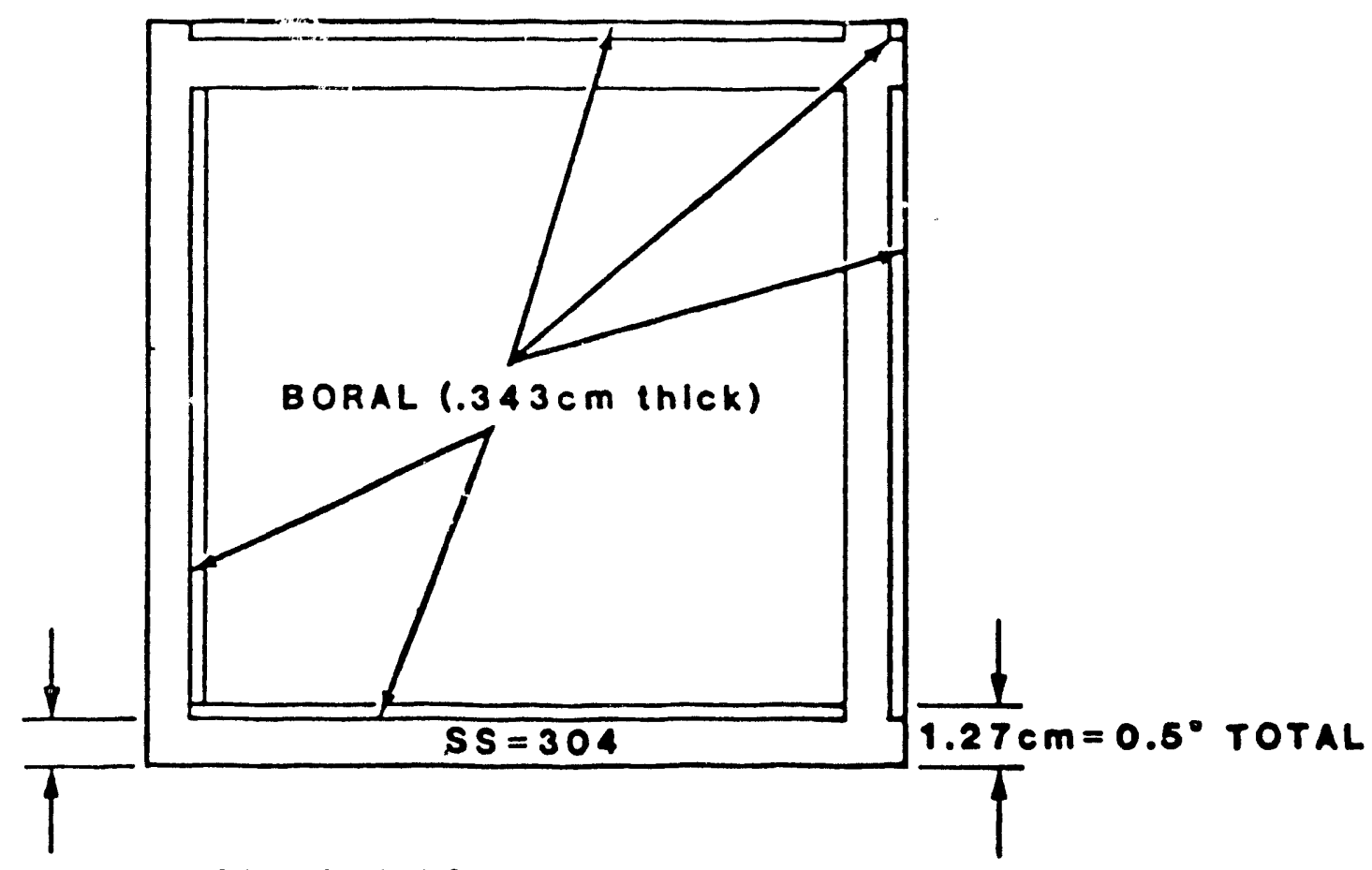

$.027 \mathrm{~cm}=1.27-.343$ BORAL

Fig. 14. Composite steel-boral basket model. 
Table 15. Basket worths for borated and nonborated webs

\begin{tabular}{|c|c|c|c|c|c|}
\hline \multirow{2}{*}{$\begin{array}{c}\text { Initial } \\
\text { enrichment }\end{array}$} & \multirow{2}{*}{$\begin{array}{c}\text { Burnup } \\
\text { GWd/MTU }\end{array}$} & \multirow[b]{2}{*}{$\mathrm{CR}^{a}$} & \multicolumn{3}{|c|}{ Basket worths, $\Delta \mathrm{k}$} \\
\hline & & & 0.5 in. $\mathrm{b} / \mathrm{ss}^{b}$ & 0.25 in. $\mathrm{b} / \mathrm{ss}$ & 0.55 in. $\mathrm{ss}^{c}$ \\
\hline $2.5 \%$ & fresh & 0.35 & - & - & - \\
\hline $2.9 \%$ & fresh & 0.39 & - & - & - \\
\hline \multirow[t]{3}{*}{$3.4 \%$} & fresh & 0.44 & 0.56 & 0.51 & - \\
\hline & 21 & 0.25 & 0.48 & - & - \\
\hline & 40 & 0.09 & 0.41 & - & - \\
\hline \multirow[t]{2}{*}{$3.8 \%$} & fresh & 0.45 & 0.54 & - & 0.20 \\
\hline & 45 & 0.10 & 0.42 & - & 0.17 \\
\hline $4.5 \%$ & fresh & 0.50 & - & 0.51 & \\
\hline
\end{tabular}

${ }^{a}$ Control requirements, see Table 12.

${ }^{b}$ Boral/stainless-steel basket material.

'Stainless-steel-only basket. 


\section{SUMMARY}

This report describing the feasibility assessment for the incorporation of burnup credit for BWR fuel consists of three major sections: a model validation to determine a valid 1-D model for the remaining work, burnup predictions to determine isotopic information necessary for loaded cask calculations, and cask reactivity predictions for a variety of cask basket designs. The resulting control requirements as a function of burnup and basket worths will help determine the adequacy of each basket type for a variety of burnup values.

Results from the model validation indicate that the two approximations necessary to model an assembly in 1-D-split-versus-average enrichments and a revised assembly/water channel model (cylindrical-versus- $x-y$ model and $1 / 6$-versusfull assembly) - do not significantly affect the overall results. Two other effects, the axial water density variation and the Gd-rod assembly modeling, required further analysis to either refine or justify the model approximations. Tine large magnitude of axial water density variations suggested that multiple axial nodes be used. Remaining calculations were performed with three equally spaced axial nodes. A better model for the Gd-rod assembly was not readily apparent; therefore, calculations were performed for non-Gd assemblies with otherwise identical models to estimate the model accuracy after the rapid depletion of $\mathrm{Gd}$ has occurred. Much better agreements were seen for the non-Gd assembly.

Subsequent calculations were performed using the 1-D model to predict the assembly isotopics as a function of burnup. These burnup calculations were made for a range of enrichments from 2.9 to $3.8 \%$ and for three axial nodes, as stated above. Four different axial power shape assumptions were made to test the sensitivity of final isotopics to $t^{1}$ e assumed time-dependent axial power shape. The final results are given for the al power assumption of Fig. 5a. The two most plausible axial power shape assumptions (Figs. $5 \mathrm{a}$ and $5 \mathrm{c}$ ) give reactivity results that differ by only $2-3 \% \Delta \mathrm{k}$.

The isotopics from these burnup calculations were then decayed for periods of 1 10 years to allow determination of the $\mathrm{k}_{e f f}$ values as a function of cooling time after irradiation. The findings show the obvious decrease of reactivity with increasing burnup, the decrease of reactivity with increasing cooling time (primarily because of ${ }^{241} \mathrm{Pu}$ decay), enhanced reactivity decreases with cooling for larger burnups, and enhanced reactivity decreases with cooling for smaller enrichments given identical burnups.

The technical feasibility of utilizing burnup credit has been demonstrated in this report. The overall decrease in $\mathrm{k}_{\infty}$ from fresh fuel to cooled spent fuel is the range of $30-40 \% \Delta \mathrm{k}$. These values are very similar to previous PWR results. However, basket worths for borated baskets were in the range of $40-50 \% \Delta \mathrm{k}$, nearly double the corresponding PWR valises. These results indicate that while the changes in reactivity over the life cycle of BWR fuel are very similar to those of PWR fuel, baskets containing boral are much more effective for BWR fuel than for PWR fuel.

The earlier report ${ }^{1}$ on the feasibility of burnup credit for PWR fuel transport established that reduced risk and economic benefits are gained from an increased cask payload. The results in this report indicate that increased capacity (over current generation designs) can also be obta.ıned for BWR casks by (1) assuming fresh fuel isotopics and using well-designed, poisoned cask baskets, or (2) utilizing the burnup credit approach with simpler, unpoisoned basket designs. Thus, the main advantage of using burnup credit in BWR transport casks is to eliminate the need for complicated basket designs containing external poisons. 


\section{REFERENCES}

1. T. L. Sanders, R. M. Westfall, and R. H. Jones, Feasibility and Incentives for the Consideration of Spent Fuel Operating Histories in the Criticality Analysis of Spent Fuel Shipping Casks, SAND87-0151, TTC-0713, Sandia National Laboratories, August 1987.

2. M. C. Brady, J. P. Renier, C. V. Parks, and T. L. Sanders, Comparison of Analysis Methods for Burnup Credit Applications, presented at the 9th International Symposium on the Packaging and Transportation of Radioactive Materials, Washington, DC, June 11-16, 1989.

3. SCALE: A Modular Code System for Performing Standardized Computer Analyses for Licensing Evaluation, Vols. 1-3, NUREG/CR-0200, U.S. Nuclear Regulatory Commission (originally issued July 1980, reissued January 1982, Revision 1 issued July 1982, Revision 2 issued June 1983, Revision 3 issued December 1984).

4. C. V. Parks, SCALE-4: An Improved Computational System for Spent-Fuel Cask Analysis, presented at the 9th International Symposium on the Packaging and Transportation of Radioactive Materials, Washingion, DC, June 11-16, 1989.

5. W. A. Khoades and R. L. Childs, DORT-A Two-Dimensional Discrete Ordinates Transport Code, Code Package CCC-484/DORT, Radiation Shielding Information Center, 1988.

6. C. V. Parks, Summary Description of the SCALE Modular Code System, NUREG/CR-5033, ORNL/CSD/TM-252, Martin Marietta Energy Systems, Inc., Oak Ridge Natl. Lab., December 1987.

7. O. W. Hermann et al., Multicode Comparison of Selected Source-Term Computer Codes, ORNL/CSD/TM-251, Martin Marietta Energy Systems, Inc., Oak Ridge Natl. Lab., April 1989.

8. R. M. Westfall, "Effects of Burnup Credit on Cask Basket Design Spacing Requirements," pp. 4j-53 Proceedings of a Workshop on the Use of Burnup Credit in Spent Fuel Transport Casks, ed. T. L. Sanders, SAND89-0018, TTC-0884, Sandia National Laboratories, October 1989. 


\section{INTERNAL DISTRIBUTION}

1. S. M. Bowman

2. M. C. Brady

3-7. B. L. Broadhead

8. J. A. Bucholz

9. O. W. Hermann

10. W. C. Jordan

11. A. P. Malinauskas

12. J. T. Mihalczo

13. L. F. Norris

14-13 C. V. Parks

19. L. M. Petrie

20. R. B. Pope

21. R. R. Rawl

22. J. P. Renier

23-24. C. H. Shappert
25. L. B. Shappert

26. G. R. Smolen

27. J. S. Tang

28. R. M. Westfall

29. G. E. Whitesides/R. P. Leinius

30-31. Laboratory Records Department

32. Laboratory Records, ORNL-RC

33. Document Reference Section

34. Central Research Library

35. ORNL Patent Section

\section{EXTERNAL DISTRIBUTION}

36. Office of Assistant Manager for Energy, Research and Development, Department of Energy, Oak Ridge Operations, P. O. Box 2001, Oak Ridge, TN 37831

37. S. Ahmed, Virginia Power Co., P.O. Box 2666, Richmond, VA 23261

38. T. Albert, Science Applications International Corp., 311 Park Place Blvd., Suite 360, Clearwater, FL 34019

39. R. Anderson, General Nuclear Systems, Inc., 220 Stoneridge Dr., Columbia, SC 29210

40. D. Andress, David Andress \& Associates, Inc., 11008 Harriet Lane, Kensington, MD 20895

41. W. Andrews, Science Applications International Corp., Nevada Nuclear Waste Storage Investigations, Valley Bank Center, 101 Convention Center Dr., Las Vegas, NV 89109

42. P. Aucoin, Nuclear Assurance Corp., 6251 Crooked Creek Rd., Norcross, GA 30092

43. S. Baker, Fublic Service Electric \& Gas Co., P.O. Box 236, MC N20, Hancocks Bridge, NJ 08038

44. G. Beeman, Pacific Northwest Laboratory, P.O. Box 999, Richland, WA 99352

45. P. C. Bennett, Sandia National Laboratories, Division 6323, Albuquerque, NM 87185

46. H. Bernard, COGEMA Service Technico-Commercial, Branche Retraitement, 2 Rue Paul Dautier, Velizy-Villacoublay, Cedex, France BP4.78141

47. J. Bickel, U.S. Department of Energy, P.O. Box 5400, Albuquerque, NM 87115

48. S. Bierman, Pacific Northwest Laboratory, P.O. Box 999, Richland, WA 99352

49. P. Bolton, Roy F. Weston, Inc., 955 L'Enfant Plaza, SW, 8th Floor, Washington, DC 20024

50. J. Boshoven, GA Technologies, Inc., P.O. Box 85608, San Diego, CA 92186-9784 
51. W. Boyd, Westinghouse Electric Corp., 200 Mall Blvd., Monroeville, PA 15146

52. D. Boyer, British Nuclear Fuels, Ltd., Risley Fleming House, Warrington, Cheshire, United Kingdom WA36AS

53. D. Brodnick, Florida Power \& Light Co., P.O. Box 14000, Juno Beach, FL 33408

54. C. Brown, Westinghouse Hanford Co., P.O. Box 1970/MNIS T5-07, Richland, WA 99352

55. M. Burgess, AEA Winfrith Technology, Reactor Physics Division, 205/B71 Winfrith Technology Centre Dorchester, Dorset, United Kingdom DT28DH

56. R. Burgoyne, GA Technologies, Inc., P.O. Box 85608, San Diego, CA 92138

57. R. Chapman, EG\&G Idaho, Inc., P.O. Box 1625, MS 1540, Idaho Falls, ID $83415-1540$

58. P. Childress, Babcock \& Wilcox, P.O. Box 10935, Lynchburg, VA 24506-0935

59. R. N. Collier, U.S. Department of Energy, P.O. Box 2002, Oak Ridge, TN 37831

60. J. Creer, Pacific Northwest Laboratory, P.O. Box 999, Richland, WA 99352

61. B. DaBell, EG\&G Idaho, Inc., P.O. Box 1625, Idaho Falls, ID 83415-9109

62. B. Darrough, U.S. Department of Energy, RW-33, Washington, DC 20545

63. J. Davis, Utility Nuclear Waste Management Group, 1111 19th St., NW, Washington, DC 20036

64. A. Dennis, Sandia National Laboratories, Albuquerque, NM 87185

65. C. Devillers, Institut de Protection et de Surete Nucleaire, Departement d'Analyse de Surete, Commissariat a l'Energie Atomique, CEN/FAR-BP No. 6, France F-92260

66. W. Dixon, U.S. Department of Energy, P. O. Box 14100, Las Vegas, NV 89114-4100

67. R. Doman, Nuclear Packaging, Inc., 1010 S. 336th St., Suite 220, Federal Way, WA 98003

68. J. Edlow, Edlow International Company, 1666 Connecticut Ave., Suite 500, Washington, DC 20009

69. L. Efferding, Westinghouse Nuclear Components Division, P.O. Box 1313, Pensacola, FL 32596

70. R. Embly, Duke Power Co., P.O. Box 33189, Charlotte, NC 28242

71. M. Evans, British Nuclear Fuels, Ltd., Sellafield, Seascale, Cumbria, United Kingdom CA201PG

72. L. Fairobent, NUMARC, 1776 Eye Street NW, Suite 300, Washington, DC 20006

73. F. Falci, U.S. Department of Energy, EM-51, Washington, DC 20545

74. M. Falzarano, Combustion Engineering, CE Power Systems, P.O. Box 500, Windsor, CT 06095-0500

75-76. L. Fischer, Lawrence Livermore National Laboratory, University of California, P.O. Box 808, Livermore, CA 94550

77. J. Fisher, Virginia Power Co., P.O. Box 2666, Richmond, VA 23261

78. M. Fisher, U.S. Department of Energy, 785 DOE Place, Idaho Falls, ID 83402

79. K. Folk, Southern Company Services, P.O. Box 2625, Birmingham, AL 35202

80. D. Frech, Duke Power Co., P.O. Box 33189, Charlotte, NC 28242 
81. S. Fukuda, Central Research Institute of Electric Power Industry, 1-6-1 Ohtemachi, Chiyoda-Ku, Tokyo, Japan 100

82. R. Garrison, U.S. Department of Energy, EM-51, Washington, DC 20545

83. H. Geiser, Gesellschaft fur Nuklear-Service mbH (GNS), Goethestr.88, Essen 1, Federal Republic of Germany, D-4300

84. D. Glazbrook, British Nuclear Fuels, Ltd., Sellafield, Seascale, Cumbria, United Kingdom CA201PG

85. N. Goldstein, Westinghouse R\&D Center, Bldg. 301-3B1, Pittsburgh, PA 15235

86. K. Golliher, U.S. Department of Energy, P.O. Box 5400, Albuquerque, NM 87115

87. R. Grenier, GA Technologies, Inc., P.O. Box 85608, San Diego, CA 92138

88. P. Han, Korea Advanced Energy Research Institute, P.O. Box 7, Daeduk-Danji, Chung-Nam, Korea 300-31

89. L. Harmon, U.S. Department of Energy, EM-51, Washington, DC 20545

90. D. L. Hartley, Sandia National Laboratories, Albuquerque, NM 87185

91. L. Hassler, Babcock \& Wilcox, P.O. Box 10935, Lynchburg, VA 24506-0935

92. K. H. Henry, EG\&G Idaho, Inc., P.O. Box 1625, MS 1540, Idaho Falls, ID $83415-1540$

93. T. Hindman, U.S. Department of Energy, EM-51, Washington, DC 20545

94. J. Holm, U.S. Department of Energy, 9800 S. Cass Ave., Bldg. 350, Argonne, IL 60439

95. B. Hopkins, Bechtel National, Inc., 15740 Shady Grove Rd., Gaithersburg, MD 20877-1454

96. J. Hummer, Westinghouse Hanford Co., P.O. Box 1970, Richland, WA 99352

97. N. Jain, Duke Power Co., P.O. Box 33189, Charlotte, NC 28242

98. M. Jensen, EG\&G Idahu, Inc., P.O. Box 1625, MS 1540, Idaho Falls, ID 83415- 1540

99. C. Johnson, Nuclear Assurance Corp., 6251 Crooked Creek Rd., Norcross, GA 30092

100. R. Jones, JNT, Inc., P.O. Box 1510, Los Gatos, CA 95031-1510

101. J. Kearney, Edison Electric Institute, 1111 19th St. NW, Washington, DC 20036

102. R. Kelleher, International Atomic Energy Agency, Division of Publications, Wagramerstrasse 5, P.O. Box 100, Vienna, Austria A-1400

103. W. Kerrick, Westinghouse Electric Corp., Bettis Atomic Power Laboratory, P.O. Box 79, West Mifflin, PA 15122

104. N. Ketzlach, The Ralph M. Parsons Co., 100 W. Walnut St., Pasadena, CA 91124

105. R. Kidman, Los Alamos National Laboratory, Group A4, MSF-611, Los Alamos, NM 87845

106. D. Klein, Center for Energy Studies, The University of Texas, 10100 Burnet Rd., Austin, TX 78758

107-109. W. I. Klein, Sandia National L :boratories, Albuquerque, NM 87185

110. R. Klotz, Combustion Engineering, CE Power Systems, P.O. Box 500, Windsor, CT 06095-0500

111. E. Knuckles, Florida Power \& Light Co., P.O. Box 029100, Miami, FL 33102

112. S. Kouba, U.S. Department of Energy, 9800 S. Cass Ave., Bldg. 350, Argonne, IL 60439

113. C. Kouts, U.S. Department of Energy, RW 33, Washington, DC 20545 
114. R. Kulbitskas, U.S. Department of Energy, Naval Reactors, NE-60, Washington, DC 20545 115. R. Kunita, Carolina Power \& Light Co., P.O. Box 1551, Raleigh, NC
27602

116. J. Ladesich, Southern California Edison Co., 2244 Walnut Grove Ave., Rosemead, CA 91770

117-119. W. Lake, U.S. Department of Energy, RW-33, Washington, DC 20545

120. R. Lambert, Electric Power Research Institute, P.O. Box 10412, Palo Alto, CA 94304

121-125. S. A. Landenberger, Sandia National Laboratories, Albuquerque, NM 87185

126. T. Laub, Sandia National Laboratories, Albuquerque, NM 87185

127. J. Leonard, U.S. Department of Energy, EH-321, Washington, DC 20545

128. T. Lesser, Nuclear Assurance Corp., 6251 Crooked Creek Rd., Norcross, GA 30092

129. C. Little, Westinghouse Electric Corp., Waste Technology Services Division, P.O. Box 286, Madison, PA 15663

130. T. Lucio, Nuclear Assurance Corp., 6251 Crooked Creek Rd., Norcross, GA 30092

131. R. E. Luna, Sandia National Laboratories, Albuquerque, NM 87185

132. R. W. Lynch, Sandia National Laboratories, Albuquerque, NM 87185

133. C. Ma, Bechtel National, Inc., P.O. Box 3965, San Francisco, CA 94119

134. M. M. Madsen, Sandia National Laboratories, Division 6322, Albuquerque, NM 87185

135. C. Marotta, 1504 Columbia Ave., Rockville, MD 20850

136. P. Marsico, Pickard, Lowe, \& Garrick, Inc., 1615 M Street NW, Suite 730, Washington, DC 20036

137. L. McCarten, Northern States Power Co., 414 Nicollet Mall, Minneapolis, MN 55401

138. E. McGuinn, Babcock \& Wilcox, P.O. Box 10935, Lynchburg, VA 24506-0935

139. B. McLeod, E. R. Johnson Associates, Inc., 10461 White Granite Dr., Suite 204, Oakton, VA 22124

140. D. Michlewicz, Roy F. Weston, Inc., 955 L'Enfant Plaza, SW, 8th Floor, Washington, DC 20024

141-142. W. Mings, U.S. Department of Energy, 785 DOE Place, Idaho Falls, ID 83402

143. G. Mummery, Central Electricity Generating Board, Nuclear Fuel Cycle Department, Sudbury House, 15 Newgate St., London, United Kingdom EC1A7AU

144. J. Murphy, ANEFCO, Inc., 904 Ethan Allen Hwy., P.O. Box 433, Ridgefield, CT 06877

145. D. Napolitano, Yankee Atomic Electric Co., 580 Main Street, Bolton, MA 01740

146. R. Ng, Combustion Engineering, CE Power Systems, P.O. Box 500, Windsor, CT 06095-0500

147. S. Nichols, Center for Energy Studies, The University of Texas, 10100 Burnet Rd., Austin, TX 78758

148. R. Odegaarden, 1263 E. 2nd Place, Mesa, AZ 85203

149. C. Orth, U.S. Department of Transportation, Federal Rail Administration, RRS-32, 400 7th St. SW, Washington, DC 20590

150. O. Ozer, Electric Power Research Institute, P.O. Box 10412, Palo Alto, CA 94304 
151. P. Pacquin, General Nuclear Systems, Inc., 220 Stoneridge Dr., Columbia, SC 29210

152. C. Peterson, U.S. Nuclear Regulatory Commission, Mail Stop 4H3, Washington, DC 20555

153. J. Peterson, U.S. Department of Energy, P.O. Box 550, Richland, WA 99352

154. G. Popper, Argonne National Laboratory, 9700 S. Cass Ave., Argonne, IL 60439

155. M. Rahimi, Roy F. Weston, Inc., 955 L'Enfant Plaza, SW, 8th Floor, Washington, DC 20024

156. B. Rasmussen, Duke Power Co., P.O. Box 33189, Charlotte, NC 28242

157. J. Richardson, Roy F. Weston, Inc., 955 L'Enfant Plaza, SW, 8th Floor, Washington, DC 20024

158. J. Roberts, U.S. Department of Energy, 9800 S. Cass Ave., Bldg. 350, Argonne, IL 60439

159. C. Rogers, Westinghouse Hanford Co., P.O. Box 1970/N1-31, Richland, WA 99352

160. J. Rollins, NUTECH, 1301 Hightower Trail, Suite 205, Atlanta, GA 30350

161. R. Rothman, U.S. Department of Energy, 9800 S. Cass Ave., Bldg. 350, Argonne, IL 60439

162. T. Saegusa, Central Research Institute of Electric Power Industry, 1-6-1 Ohtemachi, Chiyoda-Ku, Tokyo, Japan 100

163-172. T. L. Sanders, Sandia National Laboratories, Division 6323, Albuquerque, NM 87185

173-197. Sandia National Laboratories, TTC Library, Albuquerque, NM 87185

198. P. Saverot, NUMATEC, Inc., 2550 M Street NW, Suite 400, Washington, DC 20037

199. M. Schwartz, Pickard, Lowe, \& Garrick, Inc., 1615 M Street NW, Suite 730, Washington, DC 20036

200. K. Seager, Sandia National Laboratories, Division 6323, Albuquerque, NM 87185

201. W. Severson, Westinghouse Electric Corp., Nuclear Waste Department, P.O. Box 3912, Pittsburgh, PA 15230

202. H. Shimon, Wisconsin Electric Power Co., 231 W. Michigan St., Milwaukee, WI 53201

203. M. Smith, Virginia Power Co., P.O. Box 2666, Richmond, VA 23261

204. N. Smith, AEA Winfrith Technology, Reactor Physics Division, 205/B71 Winfrith Technology Centre Dorchester, Dorset, United Kingdom DT28DH

205. D. Snedeker, British Nuclear Fuels, Ltd., 2926 92nd Ave. E, Puyallup, WA 98371

206. T. Snow, Virginia Power Co., P.O. Box 2666, Richmond, VA 23261

207. P. Soung, Bechtel National, Inc., 15740 Shady Grove Rd., Gaithersburg, MD 20877-1454

208. R. Stein, U.S. Department of Energy, RW-30, Washington, DC 20545

209. T. Stevens, Babcock \& Wilcox, Nuclear Equipment Division, 91 Stirling Ave., Barberton, OH 44203

210. J. E. Stiegler, Attn: TTC Master File, Sandia National Laboratories, Albuquerque, NM 87185

211. J. Stokley, Science Applications International Corp., 1710 Goodridge Dr., McLean, VA 22102

212. K. Subbayya, Ontario Hydro, New Business Venture Division, 700 University Ave., C27-F3, Toronto, Ontario, Canada M56 1X6

213. J. Sun, Florida Power \& Light Co., P.O. Box 029100, Miami, FL 33102 
214. L. Tanguy, Institut de Protection et de Surete Nucleaire, Departement d'Analyse de Surete, Commissariat a l'Energie Atomique, CEN/FAR-BP No. 6, France F-92260

215. B. Thomas, NUTECH Engineering, 145 Martinvale Lane, San Jose, CA 95119

216. J. Thornton, Duke Power Co., P.O. Box 33189, Charlotte, NC 28242

217. H. Toffer, Westinghouse Hanford Co., P.O. Box 1970/A4-05, Richland, WA 99352

218. L. Trosten, LeBoeuf, Lamb, Leiby, and McRae, 1333 New Hampshire Ave., NW, Washington, DC 20036

219. N. Tsumranidis, University of Missouri-Rolla, Nuclear Energy Department, Rolla, MO 65401

220. M. Turnbull, AEA Winfrith Technology, Reactor Physics Division, 205/B71 Winfrith Technology Centre Dorchester, Dorset, United Kingdom DT28DH

221. S. Turner, Holtec International, 230 Normandy Circle E., Palm Harbor, FL 34683

222-237. U.S. Nuclear Regulatory Commission, Office of Nuclear Materials Safety and Safeguards, Washington, DC 20555

238-240. U.S. Nuclear Regulatory Commission, Office of Nuclear Regulatory Research, Washington, DC 20555

241. C. Vallepin, Commissariat a l'Energie Atomique, Departement des Etudes Mecaniques et Thermiques, Service d'Etudes des Systemes, Demt Syst. CEN-Saclay, Gif-sur-Yvette, Cedex, France 91191

242. T. A. Wackerly, Sandia National Laboratories, Albuquerque, NM 87185

243. M. Wangler, U.S. Department of Transportation, Office of Materials Transportation, 4007 th St., SW, Washington, DC 20590

244-251. C. C. Ward for DOE/OTI, Sandia National Laboratories, Albuquerque, NM 87185

252. A. Wells, Nuclear Assurance Corp., 6251 Crooked Creek Rd., Norcross, GA 30092

253. W. Weyer, Gesellschaft fur Nuklear-Service mbH (GNS), Goethestr.88, Essen 1, Federal Republic of Germany, D-4300

254. O. Wildgruber, Siemens AG, KWU Group, Dept. U PK 13, Hammerbacher Str. $12+14$, Erlangen, Federal Republic of Germany D-8520

255-263. R. Williams, Electric Power Research Institute, P.O. Box 10412, Palo Alto, CA 94304

264. E. Wilmot, U.S. Department of Energy, P.O. Box 14100, Las Vegas, NV 89114-4100

265. R. Wilson, Westinghouse Idaho Nuclear Co., P.O. Box 4000/MS-5208, Idaho Falls, ID 83403

266. H. Worle, EG\&G Idaho, Inc., P.O. Box 1625, MS 1540, Idaho Falls, ID 83415-1540

267. G. Wrights, Westinghouse Electric Corp., P.O. Box 355, Pittsburgh, PA 15230

268-442. U.S. Department of Energy, Office of Scientific and Technical Information, Attn: DOE/OSTI-4500-R15 UC820,Oak Ridge, TN 37831 

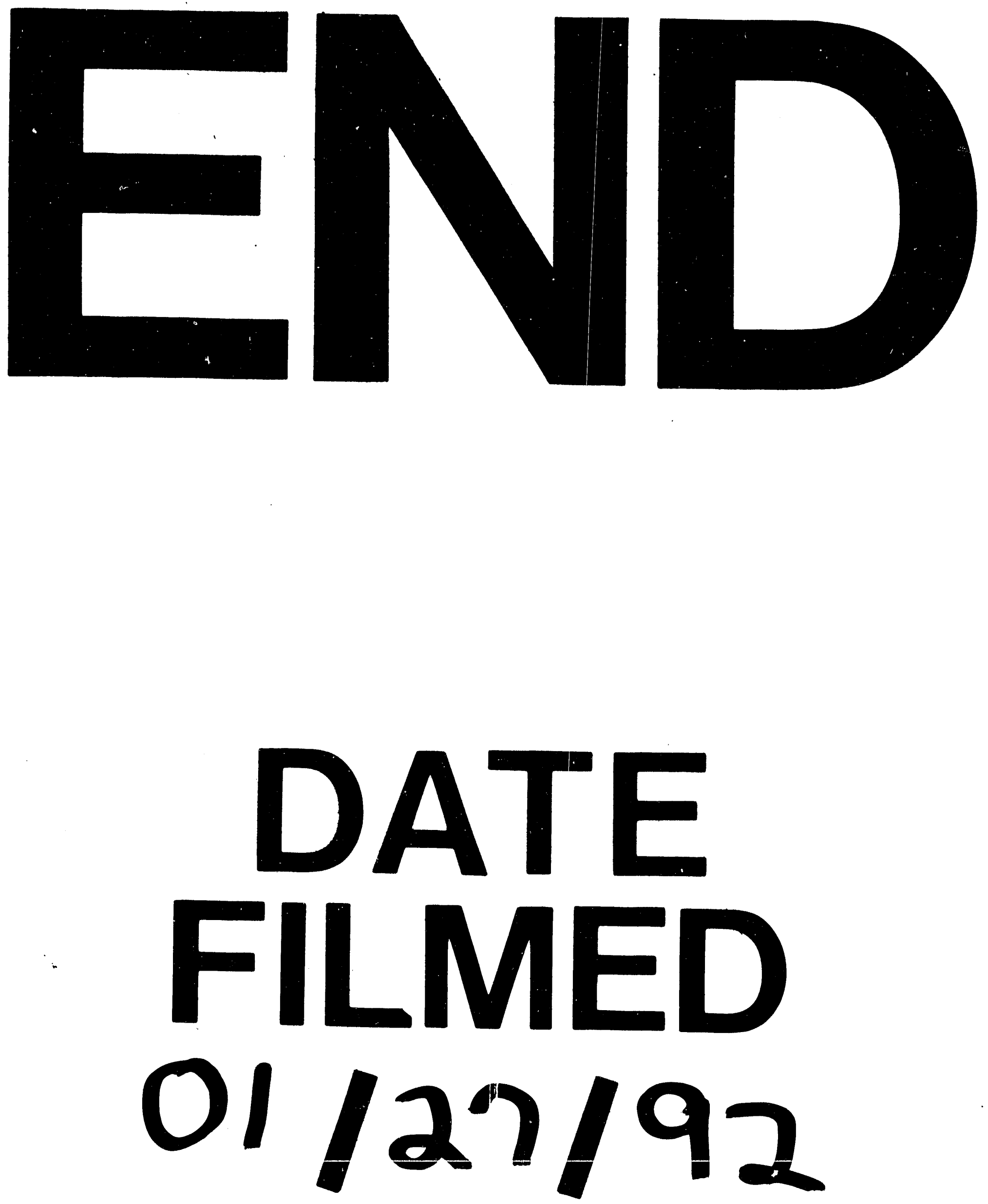
1 